Article

\title{
Impact of Diversified Chemical and Biostimulator Protection on Yield, Health Status, Mycotoxin Level, and Economic Profitability in Spring Wheat (Triticum aestivum L.) Cultivation
}

\author{
Bozena Lozowicka $^{1}$, Piotr Iwaniuk ${ }^{1, * \mathbb{D}}$, Rafal Konecki ${ }^{1}$, Piotr Kaczynski ${ }^{1}$, Nurlan Kuldybayev ${ }^{2}$ \\ and Yerlan Dutbayev ${ }^{2}$
}

Citation: Lozowicka, B.; Iwaniuk, P.; Konecki, R.; Kaczynski, P.;

Kuldybayev, N.; Dutbayev, Y. Impact of Diversified Chemical and Biostimulator Protection on Yield, Health Status, Mycotoxin Level, and Economic Profitability in Spring

Wheat (Triticum aestivum $\mathrm{L}$.)

Cultivation. Agronomy 2022, 12, 258

https://doi.org/10.3390/

agronomy12020258

Academic Editor: Enrique Eymar

Received: 6 December 2021

Accepted: 17 January 2022

Published: 20 January 2022

Publisher's Note: MDPI stays neutral with regard to jurisdictional claims in published maps and institutional affiliations.

Copyright: (C) 2022 by the authors. Licensee MDPI, Basel, Switzerland. This article is an open access article distributed under the terms and conditions of the Creative Commons Attribution (CC BY) license (https:// creativecommons.org/licenses/by/ $4.0 /)$
1 Institute of Plant Protection-National Research Institute, Chelmonskiego 22 Street, 15-195 Bialystok, Poland; b.lozowicka@iorpib.poznan.pl (B.L.); r.konecki@iorpib.poznan.pl (R.K.); p.kaczynski@iorpib.poznan.pl (P.K.)

2 Department of Plant Protection, Kazakh National Agrarian Research University, Abai Avenue 8, Almaty 050010, Kazakhstan; jalilmels@mail.ru (N.K.); yerlan.dutbayev@kaznaru.edu.kz (Y.D.)

* Correspondence: p.iwaniuk@iorpib.poznan.pl

\begin{abstract}
Biostimulators with chemical protection are a challenge in sustainable agriculture to obtain high yield, healthy, and pesticide-free wheat. The aim of this four-year spring wheat field experiment was to assess the effectivity of using herbicide, mixed fungicides protection, and a humic biostimulator. The following treatments were tested: biostimulator $(\mathrm{S})$, sulfosulfuron $(\mathrm{H}), \mathrm{H}+\mathrm{S}$, $\mathrm{H}+$ propiconazole + cyproconazole/spiroxamin + tebuconazole + triadimenol $(\mathrm{H}+\mathrm{F} 1+\mathrm{F} 2)$, and $\mathrm{H}+\mathrm{F} 1+\mathrm{F} 2+\mathrm{S}$. Evaluations of wheat yield and fungal diseases (Septoria tritici blotch, eyespot, sharp eyespot, Fusarium spp.) were performed using visual and qPCR methods. Thirteen mycotoxins were analyzed by LC-MS/MS. Infestations of six weeds were examined visually. Temperatures and precipitation data of the vegetative seasons were monitored. Precipitation most affected the occurrence of leaf diseases despite the same chemical/biostimulator treatments (up to $48 \%$ Septoria tritici blotch severity for the $\mathrm{S}$ treatment). The highest mean yield was obtained for $\mathrm{H}+\mathrm{F} 1+\mathrm{F} 2+\mathrm{S}$ $\left(5.27 \mathrm{tha}^{-1}\right)$, while the lowest level of mycotoxins was obtained for $\mathrm{H}+\mathrm{F} 1+\mathrm{F} 2\left(221.68 \mu \mathrm{g} \mathrm{kg}{ }^{-1}\right)$. For $\mathrm{H}+\mathrm{S}$, a greater reduction of mycotoxins was determined compared to the $\mathrm{H}$ treatment $(27.18 \%)$, as well as a higher severity of eyespot (18\%) and sharp eyespot (24\%). In 2017-2020, the most effective reduction of weed infestation and Fusarium spp. DNA on ears was indicated for H + F1 + F2 (16 g and $0.88 \mathrm{pg} \mathrm{g}^{-1} \mathrm{DNA}$, respectively). The greatest saved production value (196.15€) was determined for $\mathrm{H}+\mathrm{F} 1+\mathrm{F} 2+\mathrm{S}$.
\end{abstract}

Keywords: biostimulator; fungal diseases; mycotoxins; pesticides

\section{Introduction}

Cereal crops are the basic group of cultivated plants used worldwide for consumption, fodder, and industrial purposes. Cereals are rich in proteins, carbohydrates (including starch), fiber, phosphorus, zinc, silicon, fluorine, calcium, potassium, and B vitamins [1]. According to OECD/FAO [2], the estimated growth in wheat consumption by people will progress due to the growing human population. To increase the supply of wheat grain, crop protection methods contributing to higher yields and reduced occurrences of fungal diseases and mycotoxins need to be developed.

Wheat is susceptible to fungal pathogens which cause losses in yield and grain quality. Pathogenic fungi are responsible for leaf and stem diseases, contributing to severe yield and grain quality losses (e.g., Septoria tritici causes Septoria tritici blotch, Tapesia yallundae is responsible for eyespot, while Rhizoctonia cerealis causes sharp eyespot) [3]. Fungi belonging to Fusarium spp. are common microorganisms infecting cereals. In East-Central Europe, F. culmorum, F. graminearum, F. avenaceum, F. poae, and F. oxysporum occur most frequently [4]. Fusarium diseases in wheat cultivation include seedling blight, foot rot, and Fusarium 
head blight (FHB), with the highest importance in agriculture. FHB is manifested by the bleaching of spikes and, due to the accumulation of mycotoxins in industrially used grains, it is the disease that requires the most attention in wheat cultivation [5]. According to the Köppen climate classification, Poland is a country in East-Central Europe with a humid continental climate and warm summer subtype. Compared to other countries of this region (e.g., Ukraine, Belarus, Estonia, Latvia, Lithuania, Slovakia, Romania, Hungary), Poland has similar fungal diseases and mycotoxins profiles of cereals [6]. It was noticed that high precipitation and temperature affect fungi development and mycotoxins secretion; however, less is known about the efficacy of sustainable crop protection in changing climate conditions.

Fusarium mycotoxins are commonly detected in pre-harvest cereals and post-harvest grains, food products, and animal feed, which contributes to food poisonings, cancers, and/or reproduction disorders during long-term intake. Fusarium mycotoxins commonly detected in the highest amounts in East-Central Europe include deoxynivalenol (DON; up to $153 \mu \mathrm{g} \mathrm{kg}^{-1}$ ) [7], nivalenol (NIV; up to $150.8 \mu \mathrm{g} \mathrm{kg}^{-1}$ ), zearalenol (ZON; up to $284 \mu \mathrm{g} \mathrm{kg}^{-1}$ ), and HT-2 toxin (up to $40.8 \mu \mathrm{g} \mathrm{kg}^{-1}$ ) [8]; however, their occurrence is specific to species and geographical location. Moreover, according to the European Food Safety Authority (EFSA) [9], most wheat grain samples collected in Europe have DON concentration between $15.5 \mu \mathrm{g} \mathrm{kg}^{-1}$ and $410 \mu \mathrm{g} \mathrm{kg}^{-1}$, ZON between $3 \mu \mathrm{g} \mathrm{kg}^{-1}$ and $33 \mu \mathrm{g} \mathrm{kg}^{-1}$, fumonisins between $37.4 \mu \mathrm{g} \mathrm{kg}^{-1}$ and $315 \mu \mathrm{g} \mathrm{kg}^{-1}$, and NIV between $30 \mu \mathrm{g} \mathrm{kg}^{-1}$ and $430 \mu \mathrm{g} \mathrm{kg}^{-1}$. According to the European Commission Regulation No. 1881/2006 [10], the maximum allowable concentrations of DON and NIV for unprocessed cereals in food processes are up to $1250 \mu \mathrm{g} \mathrm{kg}^{-1}$ and $750 \mu \mathrm{g} \mathrm{kg}-1$, respectively, for cereals intended for direct human consumption; $2000 \mu \mathrm{g} \mathrm{kg}^{-1}$ for the feed of calves and lambs; and $900 \mu \mathrm{g} \mathrm{kg}^{-1}$ for pigs' forage, while for 3-AcDON and 15-AcDON, up to 15-20\% of DON can be achieved. Therefore, practical, diversified crop protection strategies are needed to reduce mycotoxins and provide safe grain intended for human and animal consumption. It was indicated that fludioxonil and difenoconazole are effective fungicides against the root rot of wheat, while carbendazim, thiophanate-methyl, and trifloxystrobin sufficiently combat FHB and in consequence limit the amount of mycotoxins in cereals [11,12].

Chemical protection is of major importance when it comes to the production of healthy crops (i.e., with the lowest possible level of mycotoxins). For the registration of plant protection products, the European Union was divided into three zones: the Baltic Sea, Mediterranean Sea, and Central Europe. Poland was classified in the Central zone together with Austria, Belgium, the Czech Republic, the Netherlands, Ireland, Luxembourg, Germany, Romania, Slovakia, Slovenia, Hungary, and Great Britain. Herbicides (triazolopyrimidines, sulfonoureas, and phenoxy acids) are basic pesticides used in East-Central Europe for crop protection and the reduction of weed infestation, which is the main factor limiting yield and grain quality and indirectly affecting disease severity [11]. Fungicides (triazoles, morpholines, strobilurins, and benzimidazoles) are often used as a support in herbicidal protection strategies, reducing the development of fungal diseases and, in consequence, limiting the level of mycotoxins and increasing yield and grain quality [12] However, weed infestation is mainly investigated after single herbicidal treatments, while other pesticides, e.g., fungicides, can also affect their activity [13]. On the other hand, according to the "from field to fork" strategy of the European Commission, it is recommended to reduce the use of plant protection products in agriculture.

One of the methods of sustainable agriculture is the application of biostimulators combined with chemical protection. This solution is rare in practice but can be efficient in agriculture. Biostimulators are variable natural substances and microorganisms that alleviate the negative effects of abiotic stress, participate in the physiological and biochemical processes of plants, and stimulate their development and resistance to adverse growth conditions [14]. Biostimulators based on amino acids, sodium ortho nitrophenol, sodium para nitrophenol sodium 5-nitroguaiacolate, and plant extracts combined with MCPA, dicamba, florasulam, and 2,4-D can improve wheat yield and grain quality [15-19]. Moreover, bios- 
timulators based on glutamic and organic acids, soluble carbohydrates, and microelements contributed to a higher yield, but their impact on fungal diseases and mycotoxins was not examined [20]. Biostimulators from brown algae can reduce mycotoxins level and Fusarium spp. occurrence; however, their effect on yield and leaf diseases was not investigated [21]. Humic and fulvic acids, which are components of humic biostimulators, have a positive effect on the development of lateral roots, aerial parts growth stimulation, or mitigation of the effects of water shortages and soil salinity [16]. However, their impact on fungal diseases severity and the reduction of mycotoxins level was poorly investigated. Moreover, there are limited studies concerning the effect of biostimulators combined with pesticides on health status and weed infestation in agricultural plants [17] with the practical aspect of economic efficiency.

The new insights of this study include a comprehensive assessment of the impact of various levels of chemical protection combined with a biostimulator or the exclusive use of a biostimulator as well as climatic conditions of East-Central Europe on the health status of wheat. The collateral goals were as follows: (1) evaluation of the impact of herbicide, herbicide with fungicides, and herbicide with fungicides and biostimulator on wheat yield and ergosterol content; (2) examination of fungal diseases severity and mycotoxins concentration for different crop protection strategies; (3) study of the mutual relationship between climatic conditions and quantitative and qualitative wheat grain parameters according to the diversified level of chemical/biostimulator protection; (4) and the determination of the economic profitability of different protection strategies in agricultural practice.

Taking into account the fact that the zonal registration of plant protection products in the European Union coincides with the climate zone of East-Central Europe, the results of our research can also be applied to other countries in the region.

\section{Materials and Methods}

\subsection{Field Experiment and Meteorological Data}

Spring wheat (Triticum aestivum L.) of the Mandaryna variety was cultivated in the experimental plots $\left(4 \mathrm{~m} \times 5 \mathrm{~m}\right.$; total area $\left.640 \mathrm{~m}^{2}\right)$ over four years in northeastern Poland $\left(53^{\circ} 11^{\prime} 43.6^{\prime \prime} \mathrm{N} 23^{\circ} 01^{\prime} 02.7^{\prime \prime} \mathrm{E} ; 165 \mathrm{~m}\right.$ AMSL) with a humid continental climate and warm summer subtype. After wheat harvest in each year, lupine was grown on the field as an aftercrop. The climatic conditions of this area are similar to other countries of East-Central Europe [6]. Certified seeds were sown on 4 April 2017, 6 April 2018, 3 April 2019, and 7 April 2020. Seedlings (except controls) were sprayed with commercial pesticides including herbicide sulfosulfuron ( $\mathrm{H}$, active substance; a.s.: 75\%), applied at BBCH 31 and $26.5 \mathrm{~g} \mathrm{ha}^{-1}$; fungicides (in recommended rates) F1 (propiconazole, a.s.: $22.4 \%$ + cyproconazole, a.s.: $7.16 \%$ ), applied at BBCH 32 and $200 \mathrm{~mL} \mathrm{ha}^{-1}$ and F2 (spiroxamine, a.s.: 25.25\%, tebuconazole, a.s.: $16.87 \%$, triadimenol, a.s.: 4.34\%), applied at BBCH 65 and $600 \mathrm{~mL} \mathrm{ha}^{-1}$; and a humic biostimulator improving plant growth (S, humic and fulvic acids $>95 \% ; C, N$, $\mathrm{P}_{2} \mathrm{O}_{5}, \mathrm{~K}_{2} \mathrm{O}, \mathrm{Cu}, \mathrm{Zn}, \mathrm{Mn}, \mathrm{Ni}<5 \%$; applied at BBCH 33, 47, 72; $250 \mathrm{~mL} \mathrm{ha}^{-1}$ ) (Florahumus, Sieniawa Lubuska, Poland). Commercial herbicide was purchased from Monsanto (Creve Coeur, MO, USA), commercial fungicide F1 was obtained from Syngenta (Basel, Switzerland), and commercial fungicide F2 was purchased from Bayer (Leverkusen, Germany). Treatments were carried out with a compressed air backpack sprayer with 4 nozzles (XR Tee

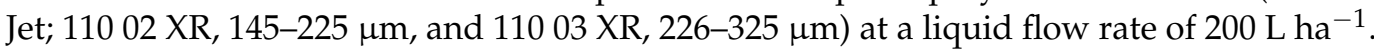
Details of the treatments are listed in Table 1 . The experiment consisted of 5 combinations and 4 repetitions each. Nitrogen $(\mathrm{N})$ / phosphorous $(\mathrm{P})$ /potassium $(\mathrm{K})$ fertilization in each year was carried out as follows: $50 \mathrm{~kg} \mathrm{~N} \mathrm{ha}^{-1}, 60 \mathrm{~kg} \mathrm{~K} \mathrm{ha}^{-1}$, and $21 \mathrm{~kg} \mathrm{P} \mathrm{ha}^{-1}$. The physical and chemical soil parameters indicated a $\mathrm{pH}$ of 7.3 and a microelements content of $1.64 \mathrm{mg} \mathrm{kg}^{-1} \mathrm{~K}_{2} \mathrm{O}, 1.72 \mathrm{mg} \mathrm{kg}^{-1} \mathrm{P}_{2} \mathrm{O}_{5}$, and $0.93 \mathrm{mg} \mathrm{kg}^{-1} \mathrm{Mg}$. Grains were harvested from each plot at the BBCH 89 stage on 27 July 2017 (1st year), 30 July 2018 (2nd year), 25 July 2019 (3rd year), and 22 July 2020 (4th year). Next, grains were separated from husks and subjected to further analysis. 
Table 1. Details of the treatments carried out in this study.

\begin{tabular}{|c|c|c|c|c|}
\hline No. & Treatment & Active Ingredient & $\begin{array}{l}\text { Active Ingredient Dose (g, } \\
\left.\mathrm{mL} \mathrm{ha} \mathrm{a}^{-1}\right)\end{array}$ & $\begin{array}{c}\text { Wheat BBCH Stage for } \\
\text { Application }\end{array}$ \\
\hline 1 & C (control) & - & - & - \\
\hline 2 & S & Humic and fulvic acids & $250 \mathrm{~mL} \mathrm{ha}^{-1}$ & $33,47,72$ \\
\hline 3 & $\mathrm{H}$ & Sulfosulfuron & $26.5 \mathrm{~g} \mathrm{ha}^{-1}$ & 31 \\
\hline 4 & $\mathrm{H}+\mathrm{S}$ & Sulfosulfuron/humic and fulvic acids & $26.5 \mathrm{~g} \mathrm{ha}^{-1} / 250 \mathrm{~mL} \mathrm{ha}^{-1}$ & $31 / 33,47,72$ \\
\hline 5 & $\mathrm{H}+\mathrm{F} 1+\mathrm{F} 2$ & $\begin{array}{c}\text { Sulfosulfuron/propiconazole }+ \\
\text { cyproconazole/spiroxamin }+ \text { tebuconazole } \\
+ \text { triadimenol }\end{array}$ & $\begin{array}{c}26.5 \mathrm{~g} \mathrm{ha}^{-1} / 200 \mathrm{~mL} \mathrm{ha}^{-1} / \\
600 \mathrm{~mL} \mathrm{ha}^{-1}\end{array}$ & $31 / 32 / 65$ \\
\hline 6 & $\mathrm{H}+\mathrm{F} 1+\mathrm{F} 2+\mathrm{S}$ & $\begin{array}{l}\text { Sulfosulfuron/propiconazole }+ \\
\text { cyproconazole/spiroxamin }+ \text { tebuconazole }+ \\
\text { triadimenol/humic and fulvic acids }\end{array}$ & $\begin{array}{l}26.5 \mathrm{~g} \mathrm{ha}^{-1} / 200 \mathrm{~mL} \mathrm{ha}^{-1} / \\
600 \mathrm{~mL} \mathrm{ha}^{-1} / 250 \mathrm{~mL} \mathrm{ha}^{-1}\end{array}$ & $31 / 32 / 65 / 33,47,72$ \\
\hline
\end{tabular}

Mean precipitation in the vegetative season was $295 \mathrm{~mm}$ in 2017 with a temperature of $13.25^{\circ} \mathrm{C}, 204 \mathrm{~mm}$ and $16.41^{\circ} \mathrm{C}$ in $2018,183 \mathrm{~mm}$ and $14.9^{\circ} \mathrm{C}$ in 2019 , and $160 \mathrm{~mm}$ and $13.7^{\circ} \mathrm{C}$ in 2020 . The temperature and precipitation data of the vegetative seasons were obtained from the meteorological station located at the experimental plots $\left(53^{\circ} 11^{\prime} 43.6^{\prime \prime} \mathrm{N}\right.$ $\left.23^{\circ} 01^{\prime} 02.7^{\prime \prime} \mathrm{E}\right)$.

\subsection{Evaluation of Wheat Yield and Fungal Diseases}

Wheat yield was assessed by harvesting all ears from $20 \mathrm{~m}^{2}$ with a plot harvester; weighting and weight from $20 \mathrm{~m}^{2}$ was extrapolated to 1 ha. Ergosterol content was assessed using an Infratec 1241 device (Foss, Hilleroed, Denmark), based on NIR (near-infrared radiation). Fungal diseases (Septoria tritici blotch, eyespot, sharp eyespot) were evaluated visually at the milk-dough growth stage (BBCH 79) in the stem base, flag, and second leaf on 25 randomly collected plants from each plot, according to the EPPO (European and Mediterranean Plant Protection Organization) scale. Disease severity was determined as low at $<20 \%$, moderate at $20-40 \%$, and high at $>40 \%$.

\subsection{Quantitative Determination of Fusarium spp.}

F. culmorum, F. avenaceum, F. graminearum, F. poae, and F. oxysporum reference strains were grown for 5 days in $23^{\circ} \mathrm{C}$ on potato dextrose agar (PDA). Next, $100 \mathrm{mg}$ of mycelium was scraped from the solid medium and DNA isolation was performed according to the modified for filamentous fungi CTAB method with a NucleoSpin Plant II Kit (MachereyNagel, Düren, Germany) as recommended by the manufacturer.

The aggregate sample of grain $(20 \mathrm{~g})$ originating from each experimental plot was ground in the mortar and $40 \mathrm{mg}$ of flour was taken for DNA isolation. DNA was extracted using a modified CTAB method with a NucleoSpin Plant II Kit (Macherey-Nagel, Düren, Germany). The concentration and purity of the isolated DNA were measured in a NanoPhotometer P300 (Implen, Munich, Germany). Next, DNA wheat samples were diluted to the working concentration $100 \mathrm{ng} \mu \mathrm{L}^{-1}$ and kept at $-20^{\circ} \mathrm{C}$ for further analysis. Real-time PCR with serial dilutions of Fusarium spp. DNA as positive controls was performed to assess accuracy and specificity in amplifying sequences of the EF1-alpha gene with following primers: F. culmorum (5'-GTAATTTTTCTGGTGGGGCT- $3^{\prime}$ and $5^{\prime}$ AACTGATTGACACGTGATGG- ${ }^{\prime}$ ), , . avenaceum ( $5^{\prime}$-ATTCATTACCCCGCTCAAGT- $3^{\prime}$ and $5^{\prime}$-TGTGGTAAGGTTTTGTGGGA-3'), F. graminearum (5'-TATCATTCGAATCGCCCTCAC$3^{\prime}$ and $5^{\prime}$-GACAGGTGGTTAGTGACTGGT-3'), F. poae (5'-GCTAACATGCTTGACAGACC$3^{\prime}$ and $5^{\prime}$-ATGGATCGAGGGAAAGTAGG-3'), and F. oxysporum (5'-CATACTGACATCGTTT CACAG-3' and $5^{\prime}$-TAGCGGGTACGTTTCGAGT- $3^{\prime}$ ). Real-time PCR for fungal and wheat samples was performed according to a previously described protocol [4]. Obtained Fusarium spp. concentrations were calculated as pg fungal DNA g ${ }^{-1}$ dry mass (dm). 


\subsection{Determination of Mycotoxins}

The mycotoxins deoxynivalenol (DON) and its acetylated forms (3-AcDON, 15AcDON), nivalenol (NIV), zearalenone (ZON), diacetoxyscirpenol (DAS), fusarenon $X$ (FusX), T-2, HT-2, fumonisins (FUM B1, FUM B2, FUM B3), and neosolaniol (NEO) were obtained from LGC (Wasel, Germany). Individual stock solutions were prepared in acetonitrile/water $(1: 1, v / v)$ at a concentration of $1 \mathrm{mg} \mathrm{mL}^{-1}$ and were used to obtain a standard mixture at the concentrations of $0.1-1000 \mu \mathrm{g} \mathrm{mL}^{-1}$. The standard mixture was stored at $-18{ }^{\circ} \mathrm{C}$. Mycotoxins were extracted using the QuEChERS method and analyzed via LC-MS/MS based on previously described protocols [8,22] (Figure 1), followed by the validation according to the Document No. SANTE/11813/2017 [23]. The details of the full analytical procedure and validation data are given in Appendix A (Tables A1-A3). A chromatogram of representative mycotoxins is shown in Figure S1.

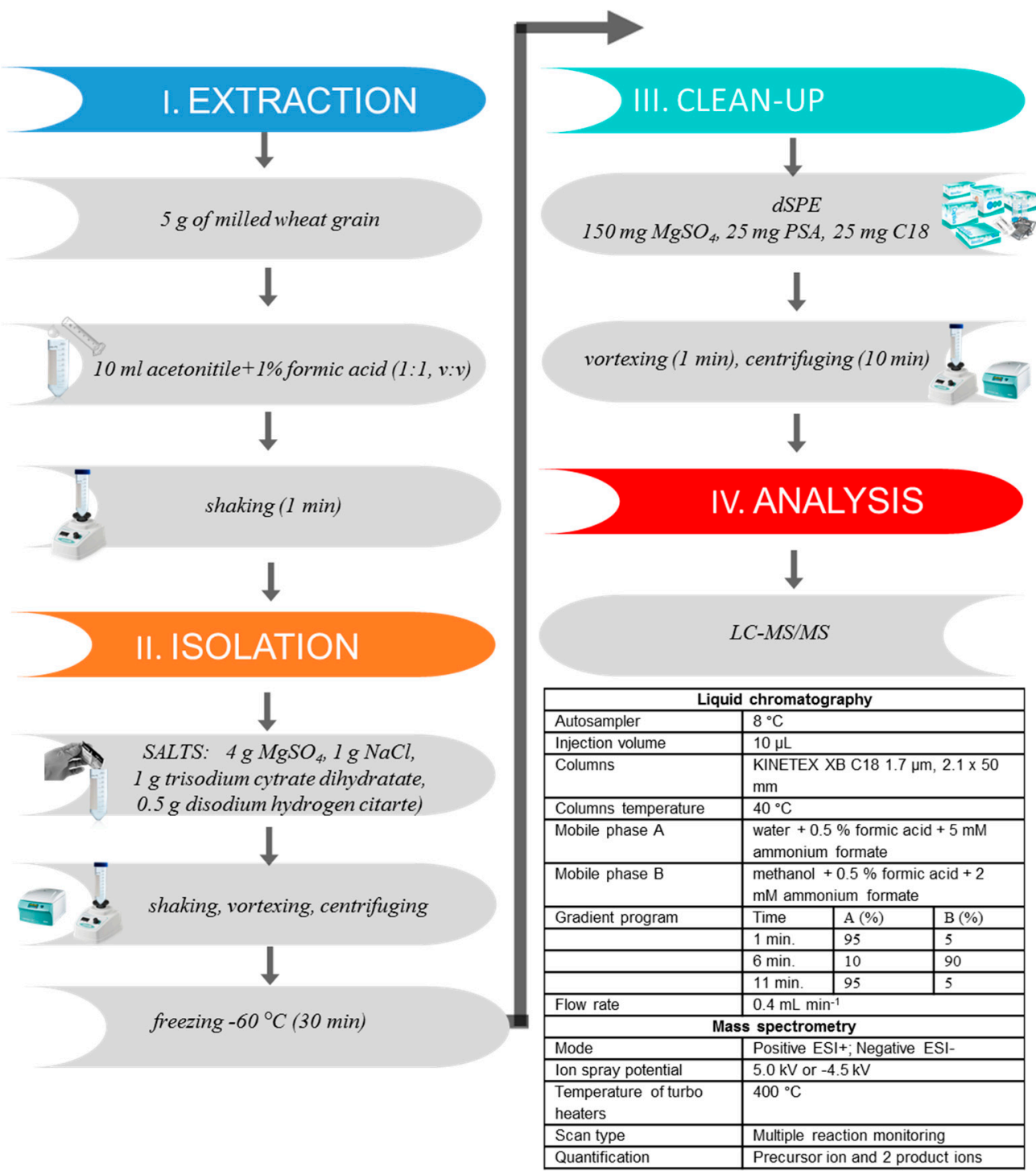

Figure 1. Scheme of wheat grain sample preparation, extraction, and analysis of mycotoxins using LC-MS/MS.

\subsection{Weed Infestation}

To assess weed infestation, all plants excluding wheat were uprooted from $1 \mathrm{~m}^{2}$ of control and all treatments. The plant material was collected in the BBCH 54 stage of wheat (heading). Weeds were cleaned from the soil particles. On the day of harvesting, the 
number and mass of the following most common species were determined: shepherd's purse (Capsella bursa-pastoris), white goosefoot (Chenopodium album), common knotgrass (Polygonum aviculare), red pimpernel (Anagallis arvensis), yellow foxtail (Setaria glauca), black bindweed (Fallopia convolvulus), and wall speedwell (Veronica arvensis).

\subsection{Economic Optimum Rate}

To assess the economic profitability of each protection strategy, the following calculations were performed:

$$
\begin{gathered}
\mathrm{E}=\mathrm{Spv} / \mathrm{Ct} \\
\mathrm{Spv}=\mathrm{Ys} \times \mathrm{C} \\
\mathrm{E}=(\mathrm{Ys} \times \mathrm{C}) / \mathrm{Ct} \\
\mathrm{Ym}=\mathrm{Ct} / \mathrm{C}
\end{gathered}
$$

where $\mathrm{E}$ is economic the efficiency $(>1), \mathrm{Spv}$ is the saved production value $(€), \mathrm{Ct}$ is the total cost of treatment (cost of plant protection products, biostimulator, average cost of fuel per hectare), Ys is the yield saved from a particular strategy compared to the control $\left(\mathrm{t} \mathrm{ha} \mathrm{a}^{-1}\right), \mathrm{C}$ is the average cost of wheat at harvest for each study year $\left(\mathrm{tha}^{-1}\right)$, and $\mathrm{Ym}$ is the minimum yield saved in a particular strategy compared to the control, justifying the profitability of the treatment. An economic efficiency above 1 indicates that the strategy is profitable in agricultural practice. The above equations were calculated for average yield and costs from the four-year study. The average costs of treatment per 1 ha in relation to the prices in Poland were as follows: biostimulator $(6.16 €)$, herbicide $(24.78 €)$, herbicide + biostimulator $(30.94 €)$, herbicide + fungicide F1 + fungicide F2 (63.32 $€$ ), and herbicide + fungicide F1 + fungicide F2 + biostimulator (69.48€). The average price of $1 \mathrm{t}$ of wheat was $163.45 €$.

\subsection{Statistical Analysis}

Analyses were conducted using one-way ANOVA and a post hoc Fisher's test (Table S1). A principle component analysis (PCA) between variables was performed. A resulting correlation matrix was visualized as a heatmap. Statistical significance was established as $p \leq 0.05$. For the examined traits, Pearson's correlation (r) was carried out for $p \leq 0.05$. All data were elaborated in STATISTICA 12 software (StatSoft, Tulsa, OK, USA).

\section{Results}

\subsection{Quality Parameters of Wheat Grain under Diverse Chemical/Biostimulator Treatments}

Despite frequent single herbicidal protection, the highest yield in the years 2017-2020 was determined for the sulfonylurea herbicide with a biostimulator $\left(\mathrm{H}+\mathrm{S} ; 6.5 \mathrm{tha}^{-1}\right)$, herbicide combined with morpholine/triazole fungicides $\left(\mathrm{H}+\mathrm{F} 1+\mathrm{F} 2 ; 6.3 \mathrm{tha}^{-1}\right)$, and the herbicidal and fungicidal treatment combined with a humic biostimulator $(\mathrm{H}+\mathrm{F} 1+\mathrm{F} 2+\mathrm{S}$; $6.1 \mathrm{t} \mathrm{ha}^{-1}$ ) (Table 2). In the four-year period, an average yield ranged from $3.43 \mathrm{tha}^{-1}$ in 2017 to $6.5 \mathrm{t} \mathrm{ha}^{-1}$ in 2018. Low yields for all combinations in 2017 are connected with high total precipitations, and they resulted in greater fungal diseases incidence. However, single biostimulator application caused a lower yield $\left(4.8 \mathrm{tha}^{-1}\right)$ compared to that of the control $\left(5.3 \mathrm{tha}^{-1}\right)$. 
Table 2. Quantitative and qualitative parameters of spring wheat grain under diverse chemical/biostimulator treatments (disease severity: low $<20 \%$, moderate $20-40 \%$, and high $>40 \%$ ). The same letter in the particular year of the study indicates that the value is not significantly different $(p \geq 0.05)$.

\begin{tabular}{|c|c|c|c|c|c|c|c|c|c|}
\hline \multirow{2}{*}{ No. } & \multirow{2}{*}{ Treatment $^{1}$} & \multirow{2}{*}{ Year } & \multirow{2}{*}{$\begin{array}{l}\text { Yield } \\
\left(t \text { ha }^{-1}\right)\end{array}$} & \multirow{2}{*}{$\begin{array}{l}\text { Ergosterol } \\
\left(\mathrm{mg} \mathrm{kg}^{-1}\right)\end{array}$} & \multirow{2}{*}{$\frac{\text { Flag Leaf }}{S^{2}(\%)}$} & \multicolumn{2}{|c|}{ Stem Basis } & \multirow{2}{*}{$\begin{array}{l}\text { Fusarium spp. } \\
\quad\left(\mathrm{pg} \mathrm{g}^{-1}\right)\end{array}$} & \multirow{2}{*}{$\begin{array}{c}\text { Mycotoxins } \\
\left(\mu \mathrm{g} \mathrm{kg}^{-1}\right)\end{array}$} \\
\hline & & & & & & $E^{3}(\%)$ & $\mathrm{SE}^{4}(\%)$ & & \\
\hline \multirow{4}{*}{1} & \multirow{4}{*}{$\mathrm{C}$} & 1 & $3.43 \mathrm{a}$ & $9 \mathrm{bcd}$ & $11 \mathrm{a}$ & $19 \mathrm{a}$ & $15 \mathrm{a}$ & $15.27 \mathrm{a}$ & $29.1 \mathrm{a}$ \\
\hline & & 2 & $5.3 \mathrm{~b}$ & $9.2 \mathrm{a}$ & $6 \mathrm{a}$ & $27 \mathrm{a}$ & $16.5 \mathrm{a}$ & $5.96 \mathrm{a}$ & 983 a \\
\hline & & 3 & $3.7 \mathrm{ab}$ & $8 a$ & - & $6.8 \mathrm{a}$ & $1.1 \mathrm{a}$ & $2.44 \mathrm{a}$ & 823.9 a \\
\hline & & 4 & $3.9 \mathrm{a}$ & $9.7 \mathrm{a}$ & - & $1.8 \mathrm{a}$ & $1.2 \mathrm{a}$ & $7.46 \mathrm{a}$ & $912.5 \mathrm{a}$ \\
\hline \multirow{4}{*}{2} & \multirow{4}{*}{$\mathrm{S}$} & 1 & $3.9 \mathrm{ab}$ & $7.8 \mathrm{abc}$ & $48 \mathrm{~b}$ & $17 \mathrm{a}$ & $17 \mathrm{a}$ & $15.52 \mathrm{a}$ & $51.9 \mathrm{~b}$ \\
\hline & & 2 & $4.8 \mathrm{a}$ & $9.2 \mathrm{a}$ & $6 a$ & $6.2 \mathrm{~b}$ & $9.6 \mathrm{~b}$ & $1.76 \mathrm{~b}$ & $383.7 \mathrm{~b}$ \\
\hline & & 3 & $3.4 \mathrm{a}$ & $7.1 \mathrm{a}$ & - & $3 a$ & $2.1 \mathrm{a}$ & $1.90 \mathrm{~b}$ & $895.3 \mathrm{a}$ \\
\hline & & 4 & $3.8 \mathrm{a}$ & $10.3 \mathrm{~b}$ & - & $1.6 \mathrm{a}$ & $0.4 \mathrm{~b}$ & $17.35 \mathrm{~b}$ & $988.8 \mathrm{a}$ \\
\hline \multirow{4}{*}{3} & \multirow{4}{*}{$\mathrm{H}$} & 1 & $4.5 \mathrm{bc}$ & $9.9 \mathrm{~d}$ & $19 \mathrm{a}$ & $21 \mathrm{a}$ & $12 \mathrm{a}$ & $13.35 \mathrm{a}$ & $52.7 \mathrm{~b}$ \\
\hline & & 2 & $5.4 \mathrm{~b}$ & $9.2 \mathrm{a}$ & $5.8 \mathrm{a}$ & $24.1 \mathrm{a}$ & $13.1 \mathrm{c}$ & $2.29 \mathrm{~b}$ & $641.1 \mathrm{c}$ \\
\hline & & 3 & $4.3 \mathrm{bcd}$ & $7.7 \mathrm{a}$ & - & $6.2 \mathrm{a}$ & $0.7 \mathrm{a}$ & $1.97 \mathrm{~b}$ & $667 \mathrm{~b}$ \\
\hline & & 4 & $4.4 \mathrm{~b}$ & $9.3 \mathrm{a}$ & - & $3.6 \mathrm{~b}$ & $0.5 \mathrm{~b}$ & $2.27 \mathrm{c}$ & $684.1 \mathrm{~b}$ \\
\hline \multirow{4}{*}{4} & \multirow{4}{*}{$\mathrm{H}+\mathrm{S}$} & 1 & $4.09 \mathrm{ab}$ & $9.3 \mathrm{~cd}$ & $43 \mathrm{~b}$ & $28 \mathrm{a}$ & $24 \mathrm{a}$ & $10.52 b$ & $75.2 \mathrm{c}$ \\
\hline & & 2 & $6.5 \mathrm{e}$ & $9.1 \mathrm{a}$ & $5.5 \mathrm{a}$ & $25.1 \mathrm{a}$ & $12.3 \mathrm{bc}$ & $8.38 \mathrm{~d}$ & $466.8 \mathrm{~d}$ \\
\hline & & 3 & $4.4 \mathrm{~cd}$ & $7.4 \mathrm{a}$ & - & $3.1 \mathrm{a}$ & $1.3 \mathrm{a}$ & $2.01 \mathrm{bc}$ & $589.8 \mathrm{c}$ \\
\hline & & 4 & $4.3 \mathrm{~b}$ & $9.7 \mathrm{a}$ & - & $2.6 \mathrm{ab}$ & $0.7 \mathrm{ab}$ & $1.39 \mathrm{~d}$ & $671.5 \mathrm{~b}$ \\
\hline \multirow{4}{*}{5} & \multirow{4}{*}{$\mathrm{H}+\mathrm{F} 1+\mathrm{F} 2$} & 1 & $4.82 \mathrm{bc}$ & $7 \mathrm{ab}$ & $47 \mathrm{~b}$ & $17 \mathrm{a}$ & $17 \mathrm{a}$ & $7.47 \mathrm{c}$ & $13.5 \mathrm{~d}$ \\
\hline & & 2 & $6.3 \mathrm{de}$ & $7.9 \mathrm{~b}$ & $3.5 \mathrm{~b}$ & $18 \mathrm{c}$ & $14 \mathrm{a}$ & $0.88 \mathrm{e}$ & $278.5 \mathrm{e}$ \\
\hline & & 3 & $4.6 \mathrm{~cd}$ & $7.4 \mathrm{a}$ & - & $5 a$ & $0.7 \mathrm{a}$ & $1.74 \mathrm{c}$ & $314.1 \mathrm{e}$ \\
\hline & & 4 & $4.7 \mathrm{c}$ & $8.3 \mathrm{c}$ & - & $2.2 \mathrm{a}$ & $0.5 \mathrm{~b}$ & $1.68 \mathrm{~d}$ & $280.6 \mathrm{~d}$ \\
\hline \multirow{4}{*}{6} & \multirow{4}{*}{$\mathrm{H}+\mathrm{F} 1+\mathrm{F} 2+\mathrm{S}$} & 1 & $5.16 \mathrm{c}$ & $6.9 \mathrm{a}$ & $42 \mathrm{~b}$ & $22 \mathrm{a}$ & $21 \mathrm{a}$ & $8.34 \mathrm{c}$ & $31.7 \mathrm{a}$ \\
\hline & & 2 & $6.1 \mathrm{~cd}$ & $8.8 \mathrm{a}$ & $3.1 \mathrm{~b}$ & $22.7 \mathrm{c}$ & $22.8 \mathrm{~d}$ & $1.86 \mathrm{~b}$ & $230.4 \mathrm{e}$ \\
\hline & & 3 & $4.9 \mathrm{~d}$ & $6.8 \mathrm{a}$ & - & $4.5 \mathrm{a}$ & $0.6 \mathrm{a}$ & $1.56 \mathrm{c}$ & $390 \mathrm{e}$ \\
\hline & & 4 & $4.9 \mathrm{c}$ & $8.4 \mathrm{c}$ & - & $1.7 \mathrm{a}$ & $0.1 \mathrm{~b}$ & $2.26 \mathrm{e}$ & $314.1 \mathrm{de}$ \\
\hline
\end{tabular}

1 Treatment: C-control; S-biostimulator; H-herbicide; F1-fungicide 1; F2-fungicide $2 .{ }^{2}$ Septoria tritici blotch. ${ }^{3}$ Eyespot. ${ }^{4}$ Sharp eyespot.

Septoria tritici blotch was observed on leaves, while eyespot and sharp eyespot were noticed on the stem. However, according to EPPO recommendations, the severity of Septoria tritici blotch was determined as high only in 2017 (>40\%) for selected combinations (Table 2). Additionally, in 2018, eyespot was noticed as moderate (20-40\%) for the control and sulfosulfuron $(\mathrm{H})$, the sulfosulfuron with biostimulator $(\mathrm{H}+\mathrm{S})$, and the herbicide combined with fungicides and biostimulator $(\mathrm{H}+\mathrm{F} 1+\mathrm{F} 2+\mathrm{S})$. A moderate severity of sharp eyespot was determined in 2017 and 2018 for selected combinations. In 2019 and 2020 , the severity of all examined fungal diseases was determined as low $(<20 \%)$. Other diseases and pests were not detected.

Ergosterol is a marker of fungal infection in plants. The most effective reduction of its concentration was determined in fungicidal treatments (Table 2$)(p<0.05)$. Additionally, ergosterol content was also lower following the application of a biostimulator in 2017 and 2019. The total concentration of ergosterol may be related to the occurrence of other fungi, which were not assessed in this study due to their low incidence.

\subsection{Evaluation of Fusarium spp. and Their Metabolites Concentration in Wheat Grain}

The occurrence of Fusarium spp. may be related to climatic conditions. Our results show that the total Fusarium spp. concentration in the four years of the study was variable. The highest content of Fusarium spp. in most combinations (up to $15.63 \mathrm{pg}^{\mathrm{DNA} \mathrm{g}}{ }^{-1} \mathrm{dm}$ ) was determined in 2017 (Figure 2) and was related to the highest precipitation and a lower temperature in this year of the study. Species composition was also diverse in individual years of the study. F. culmorum was the predominant pathogen in 2017 (7.87 $\mathrm{pg} \mathrm{g}^{-1}$ for the single biostimulator treatment), F. oxysporum in 2018 (4.84 $\mathrm{pg} \mathrm{g}^{-1}$ for the control), and F. graminearum in 2019 (1.27 $\mathrm{pg} \mathrm{g}^{-1}$ for the control). F. poae occurred in the lowest concentration, especially in 2018-2019. Moreover, in 2020, the predominant species in wheat from the control and biostimulator treatment was F. graminearum $\left(15.76 \mathrm{pg} \mathrm{g}^{-1}\right)$. 


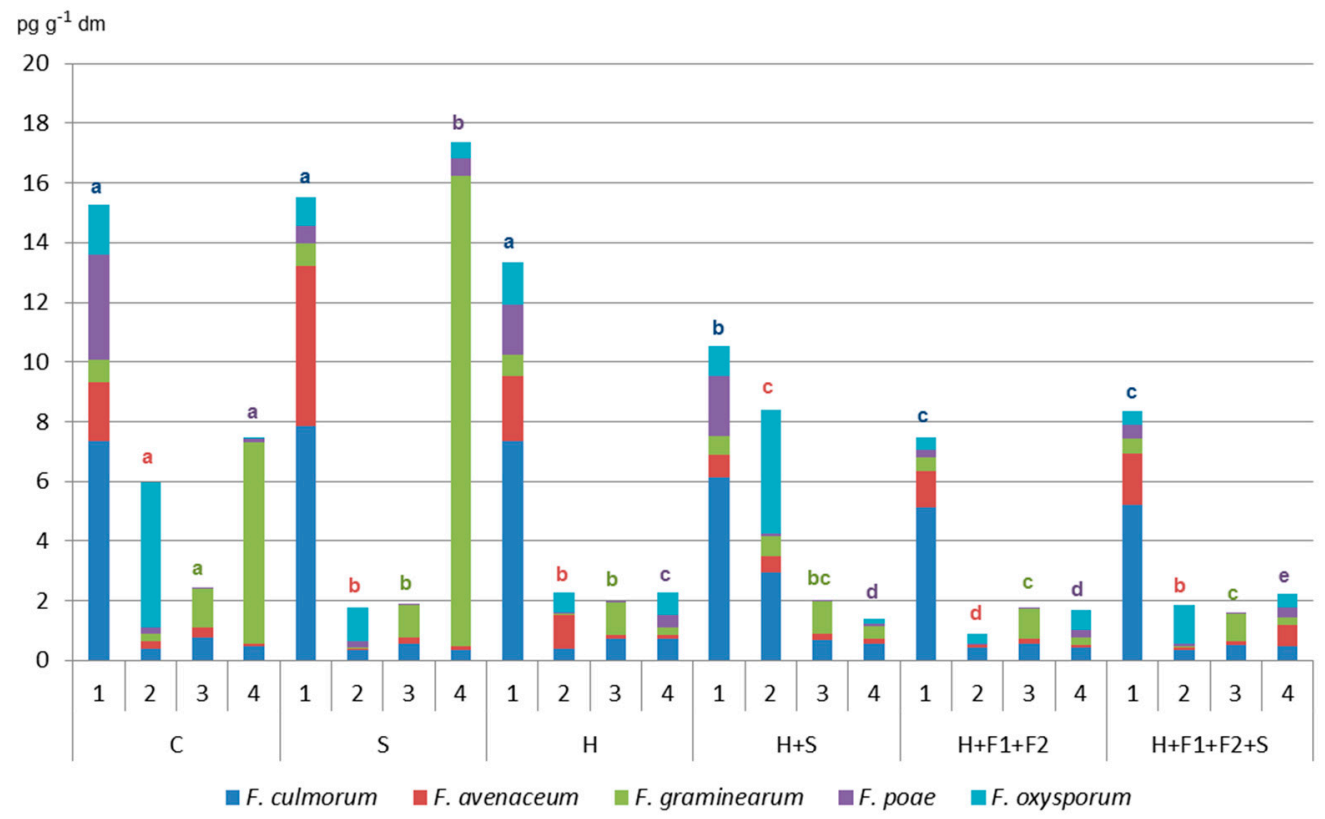

Figure 2. Concentration of Fusarium spp. in wheat grain in four years of the study (1-2017; 2-2018; 3-2019; 4-2020). C-Control; S-biostimulator; H-herbicide; F1-fungicide 1; F2-fungicide 2. Bars marked with the same letter do not differ significantly $(p \geq 0.05)$ in the particular year of the study.

The sulfonylurea herbicide combined with morpholine and triazoles fungicides $(\mathrm{H}+\mathrm{F} 1+\mathrm{F} 2)$ contributed to the most effective reduction of Fusarium spp. concentration from $7.47 \mathrm{pg} \mathrm{g}^{-1}$ in 2017 to $0.88 \mathrm{pg} \mathrm{g}^{-1}$ in 2018 (decrease of $61.57 \%$ in 2018 and $44.04 \%$ in 2017, compared to the single herbicide treatment) (Figure 2).

The mycotoxins profile was diversified in particular years of the study. From the 13 examined mycotoxins, 8 were detected in 2017 (3-AcDON, 15-AcDON, DON, NIV, ZON, HT-2, FUM B1, FUM B2), and 5 in 2018-2020 (3-AcDON, 15-AcDON, DON, NIV, ZON) (Table 3, Figure 3). Figure S1 shows the example of a chromatogram of mycotoxin standards and mycotoxins detected under the herbicide treatment of wheat in 2020. The total level of mycotoxins was the highest in $2020\left(988.8 \mu \mathrm{g} \mathrm{kg}^{-1}\right.$ for the biostimulator treatment) and the lowest in 2017 (13.5 $\mathrm{g} \mathrm{kg} \mathrm{k}^{-1}$ for the sulfonylurea herbicide combined with morpholine and triazole fungicides). Generally, treatments with morpholine and triazole fungicides were the most effective in reducing the total amount of mycotoxins $\left(13.5 \mu \mathrm{g} \mathrm{kg}^{-1}, 278.5 \mu \mathrm{g} \mathrm{kg}^{-1}\right.$, $314.1 \mu \mathrm{g} \mathrm{kg}^{-1}, 280.6 \mu \mathrm{g} \mathrm{kg}^{-1}$ in 2017-2020, respectively; reduction of $53 \%, 72 \%, 62 \%, 69 \%$, respectively). In 2020, the lowest total precipitation and Fusarium spp. concentration, but also the greatest level of mycotoxins, were observed. Interestingly, despite the lack of fungicides application, the sulfosulfuron treatment combined with a humic biostimulator $(\mathrm{H}+\mathrm{S})$ reduced mycotoxins content to $466.8 \mu \mathrm{g} \mathrm{kg}^{-1}$ in $2018(27 \%), 589.8 \mu \mathrm{g} \mathrm{kg}^{-1}$ in $2019(12 \%)$, and $671.5 \mu \mathrm{g} \mathrm{kg}^{-1}$ in $2020(2 \%)$, compared to exclusive herbicide application (Figure 3). 
Table 3. Mycotoxins concentration in diverse strategies of crop protection in four years of the study (1-2017; 2-2018; 3-2019; 4-2020). The same letter in the particular year of the study indicates that the value is not significantly different $(p \geq 0.05)$.

\begin{tabular}{|c|c|c|c|c|c|c|c|c|c|c|c|}
\hline \multirow[b]{2}{*}{ No. } & \multirow[b]{2}{*}{ Treatment $^{1}$} & \multirow[b]{2}{*}{ Year } & \multicolumn{9}{|c|}{ Mycotoxins ( $\left.\mu \mathrm{g} \mathrm{kg}^{-1}\right)$} \\
\hline & & & DON & 3-AcDON & 15-AcDON & NIV & ZON & FUM B1 & FUM B2 & HT-2 & Total \\
\hline \multirow{4}{*}{1} & \multirow{4}{*}{$\mathrm{C}$} & 1 & $15.7 \mathrm{a}$ & $0.8 \mathrm{a}$ & 0 & 0 & $8.5 \mathrm{a}$ & $1.7 \mathrm{ac}$ & 0 & $2.4 \mathrm{a}$ & $29.1 \mathrm{a}$ \\
\hline & & 2 & $229 \mathrm{~d}$ & $24 \mathrm{e}$ & $83.1 \mathrm{~d}$ & $607 \mathrm{e}$ & $39.9 \mathrm{f}$ & 0 & 0 & 0 & $983 \mathrm{a}$ \\
\hline & & 3 & $234 \mathrm{a}$ & $24.3 \mathrm{a}$ & $67.9 \mathrm{a}$ & $450 \mathrm{a}$ & $47.7 \mathrm{a}$ & 0 & 0 & 0 & $823.9 \mathrm{a}$ \\
\hline & & 4 & $243 a$ & $31.6 \mathrm{a}$ & $72.4 \mathrm{a}$ & $512 \mathrm{a}$ & $53.5 \mathrm{a}$ & 0 & 0 & 0 & $912.5 \mathrm{a}$ \\
\hline \multirow{4}{*}{2} & \multirow{4}{*}{$\mathrm{S}$} & 1 & $35.5 \mathrm{~b}$ & $0.5 \mathrm{a}$ & 0 & 0 & $8.4 \mathrm{a}$ & $4.7 \mathrm{~b}$ & 0 & $2.8 \mathrm{a}$ & $51.9 \mathrm{~b}$ \\
\hline & & 2 & $55.8 \mathrm{~b}$ & $7.9 \mathrm{c}$ & $43.2 \mathrm{bc}$ & $256 \mathrm{bc}$ & $20.8 \mathrm{~d}$ & 0 & 0 & 0 & $383.7 \mathrm{~b}$ \\
\hline & & 3 & $246 a$ & $23.7 \mathrm{a}$ & $64.3 \mathrm{a}$ & $532 \mathrm{~b}$ & $29.3 \mathrm{~b}$ & 0 & 0 & 0 & $895.3 \mathrm{a}$ \\
\hline & & 4 & 237 a & $29.8 \mathrm{a}$ & $63.2 \mathrm{a}$ & $603 \mathrm{~b}$ & $55.8 \mathrm{a}$ & 0 & 0 & 0 & $988.8 \mathrm{a}$ \\
\hline \multirow{4}{*}{3} & \multirow{4}{*}{$\mathrm{H}$} & 1 & $39.6 \mathrm{~b}$ & $1.3 \mathrm{a}$ & 0 & 0 & $8.3 \mathrm{a}$ & $1.9 \mathrm{a}$ & 0 & $1.6 \mathrm{~b}$ & $52.7 \mathrm{~b}$ \\
\hline & & 2 & $131 \mathrm{c}$ & $13.5 \mathrm{~d}$ & $46.1 \mathrm{c}$ & $425 \mathrm{~d}$ & $25.5 \mathrm{e}$ & 0 & 0 & 0 & $641.1 \mathrm{c}$ \\
\hline & & 3 & $190 \mathrm{~b}$ & $24 \mathrm{a}$ & $53.5 \mathrm{ab}$ & $358 \mathrm{c}$ & $41.5 \mathrm{a}$ & 0 & 0 & 0 & $667 \mathrm{~b}$ \\
\hline & & 4 & $173 \mathrm{~b}$ & $16.6 \mathrm{~b}$ & $40.8 \mathrm{~b}$ & $411 \mathrm{c}$ & $42.7 \mathrm{~b}$ & 0 & 0 & 0 & $684.1 \mathrm{~b}$ \\
\hline \multirow{4}{*}{4} & \multirow{4}{*}{$\mathrm{H}+\mathrm{S}$} & 1 & $65.6 \mathrm{c}$ & $0.8 \mathrm{a}$ & 0 & 0 & $7.6 \mathrm{a}$ & $1.2 \mathrm{a}$ & 0 & $0 \mathrm{c}$ & $75.2 \mathrm{c}$ \\
\hline & & 2 & $64.8 \mathrm{~b}$ & $5.4 \mathrm{~b}$ & $35.5 \mathrm{~b}$ & $345 \mathrm{~cd}$ & $16.1 \mathrm{c}$ & 0 & 0 & 0 & $466.8 \mathrm{~d}$ \\
\hline & & 3 & $163 \mathrm{bc}$ & $14.6 \mathrm{~b}$ & $44.7 \mathrm{bc}$ & $339 c$ & $28.5 \mathrm{~b}$ & 0 & 0 & 0 & $589.8 \mathrm{c}$ \\
\hline & & 4 & $144 \mathrm{c}$ & $13.9 \mathrm{~b}$ & $44.6 \mathrm{~b}$ & $425 \mathrm{c}$ & $44 \mathrm{~b}$ & 0 & 0 & 0 & $671.5 \mathrm{~b}$ \\
\hline \multirow{4}{*}{5} & \multirow{4}{*}{$\mathrm{H}+\mathrm{F} 1+\mathrm{F} 2$} & 1 & $2.7 \mathrm{~d}$ & $1.1 \mathrm{a}$ & 0 & 0 & $7.4 \mathrm{a}$ & $2.0 \mathrm{c}$ & 0 & $0.3 \mathrm{~d}$ & $13.5 \mathrm{~d}$ \\
\hline & & 2 & $28.6 \mathrm{a}$ & $4.5 \mathrm{~b}$ & $33.3 \mathrm{~b}$ & $205 \mathrm{ab}$ & $7.1 \mathrm{~b}$ & 0 & 0 & 0 & $278.5 \mathrm{e}$ \\
\hline & & 3 & 88.2 de & $3.5 \mathrm{c}$ & $26.8 \mathrm{~d}$ & $186 \mathrm{e}$ & $9.6 \mathrm{f}$ & 0 & 0 & 0 & $314.1 \mathrm{e}$ \\
\hline & & 4 & $80.1 \mathrm{de}$ & $3 c$ & $17.8 \mathrm{~d}$ & $171 \mathrm{e}$ & $8.7 \mathrm{~d}$ & 0 & 0 & 0 & $280.6 \mathrm{~d}$ \\
\hline \multirow{4}{*}{6} & \multirow{4}{*}{$\mathrm{H}+\mathrm{F} 1+\mathrm{F} 2+\mathrm{S}$} & 1 & $18.3 \mathrm{a}$ & $0.5 \mathrm{a}$ & 0 & 0 & $8.1 \mathrm{a}$ & $2.3 \mathrm{c}$ & $0.6 \mathrm{a}$ & $1.9 \mathrm{~b}$ & $31.7 \mathrm{a}$ \\
\hline & & 2 & $14.3 \mathrm{a}$ & $1.9 \mathrm{a}$ & $14.8 \mathrm{a}$ & $195 \mathrm{ab}$ & $4.4 \mathrm{ab}$ & 0 & 0 & 0 & $230.4 \mathrm{e}$ \\
\hline & & 3 & $67.3 \mathrm{~d}$ & $5.8 \mathrm{c}$ & $39.2 \mathrm{ce}$ & $261 \mathrm{~d}$ & $16.7 \mathrm{ce}$ & 0 & 0 & 0 & $390 \mathrm{e}$ \\
\hline & & 4 & $72.1 \mathrm{~d}$ & $3.3 \mathrm{c}$ & $28.9 c$ & 199 ef & $10.8 \mathrm{~d}$ & 0 & 0 & 0 & $\begin{array}{c}314.1 \\
\text { de }\end{array}$ \\
\hline
\end{tabular}

${ }^{1}$ Treatment: C-control; S-biostimulator; H-herbicide; F1—fungicide 1; F2—fungicide 2.

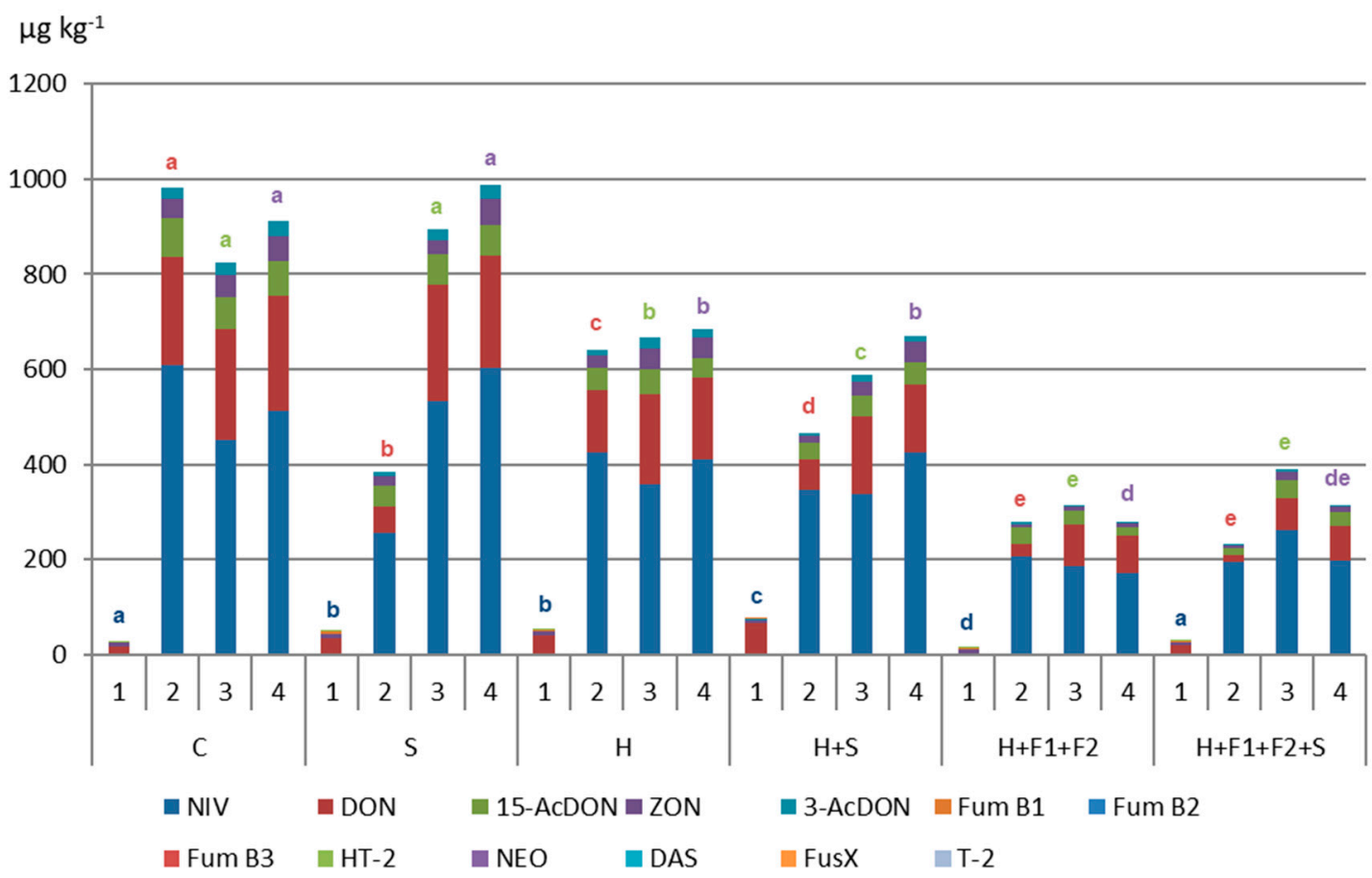

Figure 3. Mycotoxins concentration in wheat grain in four years of the study $(1-2017 ; 2-2018$; 3-2019; 4-2020). C-Control; S-biostimulator; H-herbicide; F1-fungicide 1; F2-fungicide 2. Bars marked with the same letter do not differ significantly $(p \geq 0.05)$ in the particular year of the study. 
Deoxynivalenol (DON) was predominant only in 2017, while NIV was determined to have the highest concentration in 2018-2020 (Table 3). Additionally, HT-2, FUM B1, and FUM B2 were noticed only in 2017.

\subsection{Weed Infestation}

Weed infestation is a main factor affecting crop quantitative and qualitative parameters. Thus, exclusive fungicidal treatments are not performed in agricultural practice. In the four-year period of the research, seven common weed species were noticed: Capsella bursapastoris, Chenopodium album, Polygonum aviculare, Anagalis arvensis, Setaria glauca, Fallopia convolvulus, and Veronica arvensis. The number of weeds was the highest in 2017 (up to 84 pieces per $1 \mathrm{~m}^{2}$ ) and was caused by the greatest precipitation $(293 \mathrm{~mm})$.

Biostimulator application resulted in the greatest biomass of weeds compared to the control (430 g) (Figure 4). Herbicide combined with fungicides and enriched by a humic biostimulator caused a higher number and biomass of weeds compared to the treatment without biostimulator addition (84 pieces per $1 \mathrm{~m}^{2}$ and $145 \mathrm{~g}$, a $44 \%$ increase). Interestingly, the most efficient reduction of weed infestation in 2017-2020 was noticed for the sulfonylurea treatment combined with morpholine and triazole fungicides (up to 12 pieces per $1 \mathrm{~m}^{2}$ and $16 \mathrm{~g}$ in 2019). However, weed biomass is a more effective method for weed infestation evaluation.

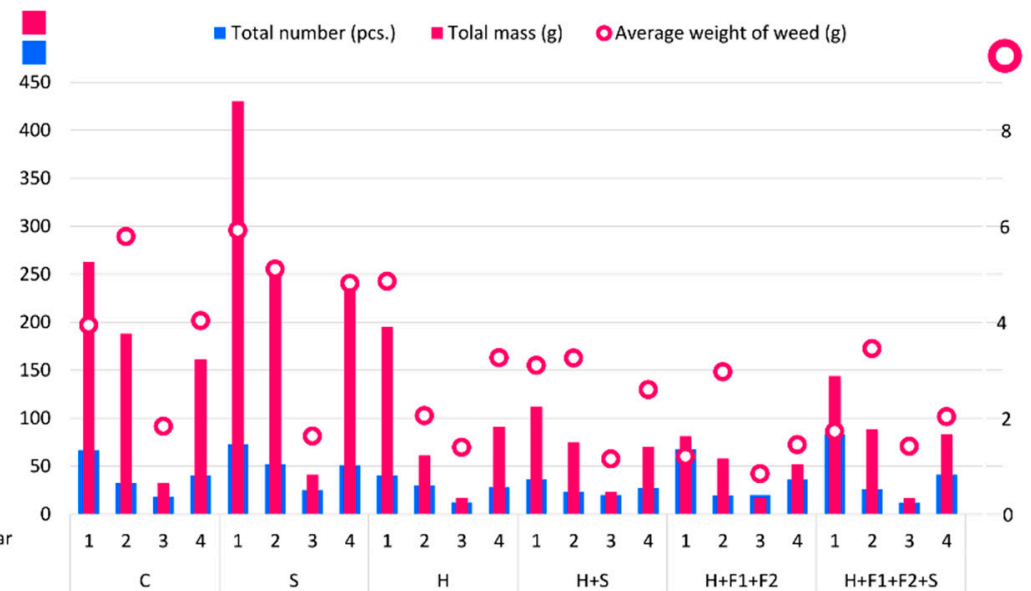

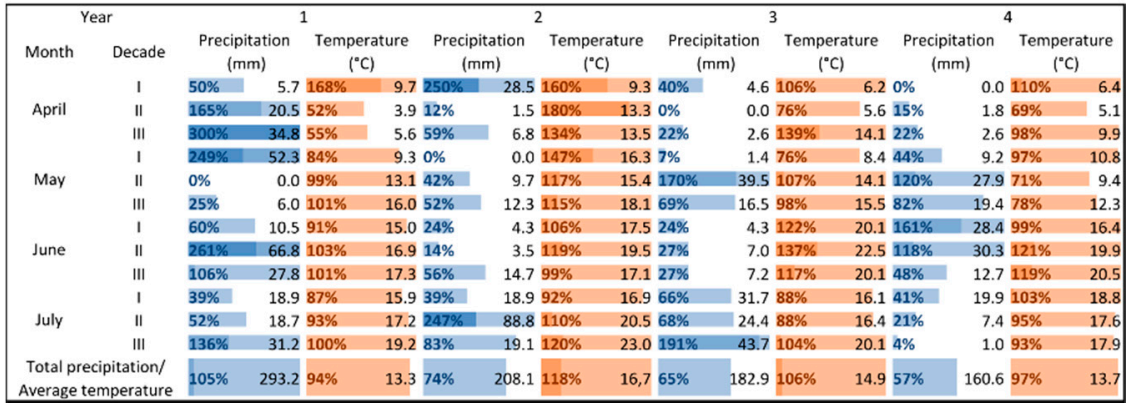

Figure 4. Total weed infestation in wheat tillage and climatic conditions: temperatures $\left({ }^{\circ} \mathrm{C}\right)$ and precipitation (mm) of northeastern Poland (1-2017; 2-2018; 3-2019; 4-2020). Percentage values are related to the mean from the last decade (values below $100 \%$ indicate temperature/precipitation decrease relative to the last 10 years). C—Control; S-biostimulator; H-herbicide; F1—fungicide 1; F2-fungicide 2.

\subsection{Economic Optimum Rates of Different Protection Strategies}

Economic calculations indicated that all protection strategies were profitable in agricultural practice $(E>1)$, except for the exclusive biostimulator treatment ( $E=-1.55)$ (Figure 5). However, the greatest economic efficiency was noticed in the case of the exclusive sulfosulfuron treatment $(\mathrm{E}=3.36)$ despite the lowest saved production value $\left(98.07 €\right.$ for $\left.0.6 \mathrm{t} \mathrm{ha}^{-1}\right)$. 
Moreover, the highest yield saved (1.2 $\left.\mathrm{t} \mathrm{ha}^{-1}\right)$ and the greatest saved production value $(196.15 €)$ due to the protection strategies were determined in the herbicidal and fungicidal treatment combined with a biostimulator $(\mathrm{H}+\mathrm{F} 1+\mathrm{F} 2+\mathrm{S})$. Furthermore, taking under consideration the total costs of the treatment and the greatest minimum yield, the lowest economic efficiency among the chemical trials was noticed for sulfonylurea, morpholine, and triazoles $(\mathrm{H}+\mathrm{F} 1+\mathrm{F} 2)(\mathrm{E}=2.41)$ (Figure 5).

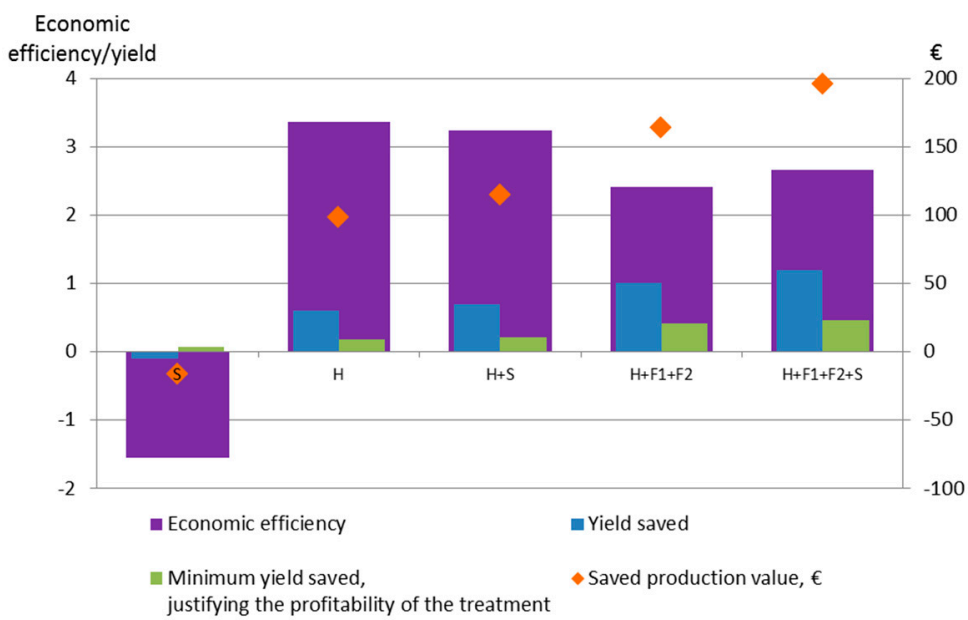

Figure 5. Economic efficiency, yield saved, minimum yield justifying the profitability of the treatment, and saved production value between diverse protection strategies. Figure shows average values from four seasons.

\subsection{Statistical Analysis}

In order to understand the significance of the results obtained, statistical analysis was performed. Figure $6 a, b$ shows the PCA analysis indicating the influence of the type of chemical treatment, temperature, and precipitation on yield, ergosterol content, Septoria tritici blotch, eyespot, sharp eyespot, Fusarium spp., mycotoxins concentration in grain, weed number, and biomass in wheat cultivation in 2017-2020. The principal component analysis explained $71.27 \%$ of the total variability among all the examined parameters and $68.54 \%$ of the variability between the mycotoxins, Fusarium spp., and climatic conditions. During the four-year study, in 2017, the highest precipitation, disease severity, and Fusarium spp. concentration along with the lowest temperature and level of mycotoxins were observed. The heatmap of the examined parameters based on Pearson's correlation coefficients indicated a positive correlation between precipitation and Septoria tritici blotch, eyespot, and sharp eyespot $(r=0.9, r=0.64, r=0.83$, respectively) (Figure 6c). Additionally, a correlation between eyespot and sharp eyespot $(r=0.86)$ was determined. Moreover, a positive correlation between precipitation and Fusarium spp. $(\mathrm{r}=0.69)$ was indicated and a negative correlation was observed between precipitation and mycotoxins $(\mathrm{r}=-0.73)$. Weed number and biomass were positively correlated with precipitation $(r=0.64 ; r=0.49$, respectively), Septoria tritici blotch $(r=0.68 ; r=0.47$, respectively), sharp eyespot $(r=0.49$; $\mathrm{r}=0.42$, respectively), and Fusarium spp. $(\mathrm{r}=0.69 ; \mathrm{r}=0.74$, respectively), and negatively correlated with temperature $(\mathrm{r}=-0.54 ; \mathrm{r}=-0.29$, respectively) and mycotoxins concentration ( $\mathrm{r}=-0.43 ; \mathrm{r}=0.24$, respectively). Ergosterol did not significantly correlate with any of the examined parameters, while wheat yield was positively correlated with temperature $(\mathrm{r}=0.62)$ and eyespot $(\mathrm{r}=0.51)$, and negatively correlated with Fusarium spp. $(\mathrm{r}=-0.37)$. The four-year study indicated that 3-AcDON, 15-AcDON, DON, NIV, and ZON were negatively correlated with precipitation (up to $\mathrm{r}=-0.76$ ), while HT-2 and FUM B1 were positively correlated ( $\mathrm{r}=0.75, \mathrm{r}=0.82$, respectively) (Figure 6c). Our study indicated negative correlations between F. culmorum, F. avenaceum, and 3-AcDON, 15-AcDON, DON, $\mathrm{NIV}$, and ZON (up to $\mathrm{r}=-0.71$ ) and positive correlations between F. culmorum, F. avenaceum, 
and HT-2 and FUM B1 (up to $\mathrm{r}=0.88$ ). In the four-year study, F. graminearum was positively correlated with 3-AcDON, 15-AcDON, DON, NIV, and ZON.

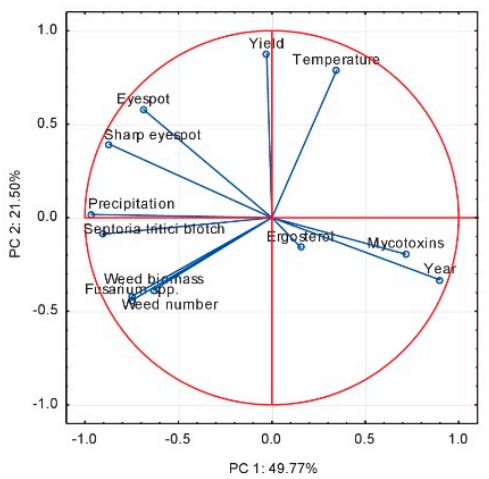

(a)

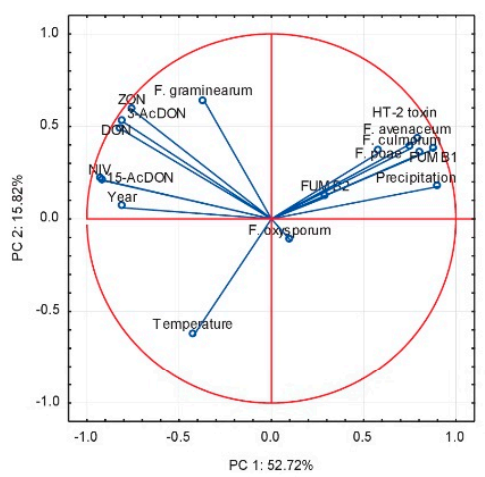

(b)

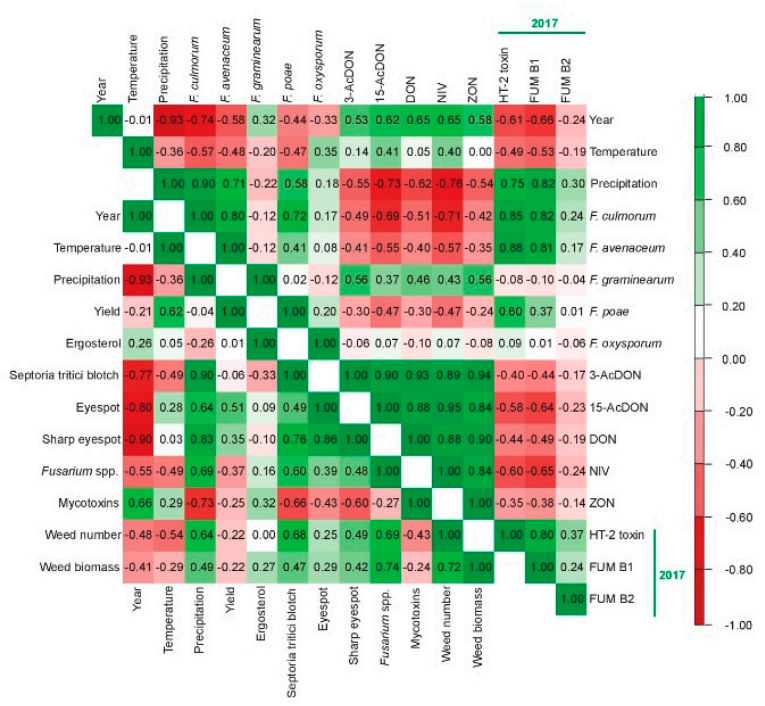

(c)

Figure 6. (a) Principal component analysis of the chemical and biostimulator treatment impact on the examined wheat grain parameters in 2017-2020. (b) Detailed principal component analysis of the chemical and biostimulator treatment impact on the particular Fusarium spp. and mycotoxins occurrence in 2017-2020. (c) Heatmap based on Pearson's correlation coefficients. Mutual correlation between examined parameters in wheat grain in 2017-2020.

\section{Discussion}

Despite the same pesticide/biostimulator protection during the four years of the study, precipitation and temperature had the most influence on the examined parameters and 
uncertainties between them. Moreover, biostimulator treatments are more sufficient in warmer years and higher air humidity decreases their efficacy.

Our results indicated an improvement of wheat yield after the application of a biostimulator based on humic acids. It was also determined that other biostimulators, e.g., with plant hormones, resulted in a higher yield [21], but algae extract and nitrophenol biostimulators have no effect or slightly reduce wheat yield if combined with pesticides [24]. Apart from sulfosulfuron in wheat, an improvement in yield was also indicated for pyrazosulfuron singly applied [25]. However, yield increase after herbicide application is not obvious. A lower wheat yield was determined under isoproturon protection [24].

The use of fungicides prior to the onset of disease symptoms was indicated to be the most effective strategy for controlling leaf diseases [26,27]. Biostimulators may promote mycorrhizal fungi growth but also indirectly contribute to the development of fungal plant pathogens, as revealed in our results. There are numerous studies showing the different effects of fungicides application on Fusarium spp. reduction; however, in field experiments, the efficacy of fungicides is often examined exclusively without herbicidal protection. It was noticed that $250 \mathrm{mg} \mathrm{L}^{-1}$ of propiconazole [28], metconazole ( $\left.1 \mathrm{~L} \mathrm{ha}^{-1}\right)$, tebuconazole (1 $\left.\mathrm{kg} \mathrm{ha}^{-1}\right)$, prochloraz (1.1 $\left.\mathrm{L} \mathrm{ha}^{-1}\right)$, and prothioconazole $\left(0.8 \mathrm{~L} \mathrm{ha}^{-1}\right)$ [29] singly applied are effective fungicides against Fusarium spp. Our results indicate that the use of a sulfonylurea herbicide $\left(26.5 \mathrm{~g} \mathrm{ha}^{-1}\right)$ combined with propiconazole and cyproconazole (a total of $200 \mathrm{~mL} \mathrm{ha}^{-1}$ ) and spiroxamine, tebuconazole, and triadimenol (a total of $600 \mathrm{~mL} \mathrm{ha}^{-1}$ ) fungicides is the best strategy to reduce Fusarium spp. in wheat under field conditions (Figure 2). Apart from fungicides, sulfosulfuron singly applied also reduced the amount of Fusarium spp. due to the reduction of weed number and humidity, which favors fungi development. Interestingly, glyphosate-based herbicides can intensify the colonization of crops by fungi due to glyphosate interactions with the metabolic pathways of selected microorganisms [30]. However, Sanyal et al. [31] observed a lower amount of Fusarium spp. on green pea after glyphosate treatment. This indicates that the severity of fungal diseases is dependent on the type of herbicide, plant species, and phytoalexins, which can interact with microorganisms.

In 2020, the lowest total precipitations and Fusarium spp. concentrations, but also the greatest level of mycotoxins, were observed, which indicates that, in contrast to some studies [32,33], Fusarium secondary metabolites are secreted in the climatic conditions (especially humidity) that are unfavorable for fungal growth [34]. Moreover, it can be assumed that despite a lower Fusarium spp. severity in drier years, mycotoxins concentration is higher in cereal cultivation. This shows that abiotic environmental stress conditions probably intensified the expression of mycotoxin co-products in fungal biosynthesis pathways. To the best of our knowledge, this is the first study indicating lower mycotoxins contamination due to herbicidal protection combined with a humic biostimulator (Table 3, Figure 3). It was also previously indicated that herbicide MCPA can decrease the concentration of 3-AcDON and $\mathrm{ZON}$ mycotoxins in wheat grain [8]. In addition to our results, it was noticed that prothioconazole (87.5 $\left.\mathrm{g} \mathrm{ha}^{-1}\right)$, azoxystrobin $\left(60 \mathrm{~g} \mathrm{ha}^{-1}\right)$, and fluxapyroxad $\left(40 \mathrm{~g} \mathrm{ha}^{-1}\right)$ limit mycotoxins concentration in wheat grain [35]. Moreover, treatments based on epoxiconazole $\left(0.5 \mathrm{~L} \mathrm{ha}^{-1}\right)$, pyraclostrobin $\left(0.5 \mathrm{~L} \mathrm{ha}^{-1}\right)$ and, mancozeb $\left(1 \mathrm{~kg} \mathrm{ha}^{-1}\right)$ did not reduce mycotoxins concentration or even induce DON amount [36]. We concluded that treatment including sulfosulfuron (750 $\left.\mathrm{g} \mathrm{L}^{-1}\right)$, propiconazole $\left(250 \mathrm{~g} \mathrm{~L}^{-1}\right)$, cyproconazole $\left(80 \mathrm{~g} \mathrm{~L}^{-1}\right)$, spiroxamine $\left(250 \mathrm{~g} \mathrm{~L}^{-1}\right)$, tebuconazole $\left(167 \mathrm{~g} \mathrm{~L}^{-1}\right)$, and triadimenol $\left(43 \mathrm{~g} \mathrm{~L}^{-1}\right)(\mathrm{H}+\mathrm{F} 1+\mathrm{F} 2)$ is the best strategy to most effectively reduce mycotoxins accumulation in cereals; however, humic biostimulator addition to the herbicidal protection can also decrease mycotoxins concentration. Our results indicate that the level of particular mycotoxins in different years may be diverse depending on the type of treatment, climatic condition during crop season, or occurrence of variable Fusarium spp. and other fungi which secrete different profiles of secondary metabolites [37].

Moreover, it was noticed that ergosterol concentration increases during grains ageing and can be dependent on precipitation [30]; however, our study did not confirm the relation 
of ergosterol to climatic conditions, though a slight positive correlation with mycotoxins content was indicated $(\mathrm{r}=0.32)$ during the four-year study. The number of weeds was the highest in 2017 (up to 84 pieces per $1 \mathrm{~m}^{2}$ ) and was caused by the greatest precipitation $(293 \mathrm{~mm})$. The biostimulator also contributed to a greater weed infestation compared to treatments without its use. This results from the non-selective action of biostimulators, which promote wheat growth but also indirectly contribute to the increased development of weeds [38]. Similar to some other studies [39], biostimulator addition is not effective in weed control as it often causes higher weed infestation and, as a consequence, the development of fungal diseases. However, in contrast to amidosulfuron, iodosulfuron, mefenpyr-diethyl, and propoxycarbazone-sodium herbicides combined with prochloraz, tebuconazole, and proquinazid $[40,41]$, sulfosulfuron protection combined with fungicides was the most effective in weed infestation reduction compared to single herbicide application. However, weed infestation was not observed after the application of biostimulator ComCat based on plant extracts [42].

In contrast to a "from field to fork" strategy, more complex chemical protection including herbicides and fungicides can contribute to better wheat parameters. As indicated by Hossard et al. [43], the reduction of pesticides dose by $50 \%$ caused a lower wheat yield (up to 10\%); therefore, efficient programs should be developed which are based on different classes of biostimulators and could replace or modulate the positive effects of pesticides on target plants' protection. Moreover, integrated plant management with crop rotation can also increase yield and contribute to the reduction of weed infestation. Brankov et al. [44] confirmed that crop rotation with winter wheat caused a higher yield and lower weed infestation in maize cultivation. Moreover, the tillage system of crop production reduced disease severity and the concentration of the DON mycotoxin in wheat with a maize rotation system [45].

Many studies aim to minimize diseases' severity and achieve the greatest yields in different protection strategies and diversified climatic conditions. However, there are not many reports showing the economic proficiency of the results obtained in agricultural practice [46]. The findings indicated in this study enabled a compromise between the most desired protection strategy with high quality yield, low diseases severity, mycotoxins concentration, and the most beneficial economic profitability. Therefore, it can be assumed that complex protection including sulfonylurea herbicides combined with morpholine and triazole fungicides and a humic biostimulator best meets these conditions.

\section{Conclusions}

Optimal chemical/biostimulator protection is crucial for obtaining safe and healthy wheat grain with low fungal diseases severity and mycotoxins level. The results of our research are a response to the current problems in the cultivation of wheat affected by fungal diseases and weeds, and therefore may have a universal character in the countries of Central and Eastern Europe. Despite the same chemical/biostimulator protection, differences related to climatic conditions of East-Central Europe in yield, disease severity, Fusarium spp. concentration, and mycotoxins level were observed in individual years of the study. Complex chemical treatment, including a sulfonylurea herbicide, morpholine, and triazole fungicides, is the most effective strategy to obtain high yield and wheat grain of good quality with a low level of fungi and mycotoxins contamination. Furthermore, the addition of a humic biostimulator reduced mycotoxins level in herbicidal treatment, but negative effects, such as fungal diseases and higher weed infestation, were observed in the treatments enriched with a biostimulator. The effectiveness of the positive action of the humic biostimulator depends on climatic conditions. Exclusive sulfonylurea treatment had a relatively high disease severity and mycotoxins level. However, considering economic profitability, herbicidal treatment combined with fungicides and a biostimulator is the most valuable and has the greatest saved production value. These research findings indicated that humic biostimulators can support chemical treatment in the reduction of 
mycotoxins and fungal diseases in particular climatic conditions and could be implemented in agricultural practice.

Supplementary Materials: The following supporting information can be downloaded at: https: / / www.mdpi.com/article/10.3390/agronomy12020258/s1. Figure S1: Chromatogram of mycotoxin standards (A,C) and wheat sample under herbicidal treatment in 2020 (B,D), Table S1: Results of ANOVA in examined parameters during four years of the study.

Author Contributions: Conceptualization, B.L.; methodology and formal analysis, P.I., R.K., P.K., N.K. and Y.D.; investigation, B.L., P.I. and P.K.; writing-original draft preparation, P.I.; writingreview and editing, B.L.; supervision, B.L. All authors have read and agreed to the published version of the manuscript.

Funding: This study was partially funded by the polish Ministry of Education and Science based on the designated subsidy within the statutory activities (SIB-01, SIB-03).

Institutional Review Board Statement: Not applicable.

Informed Consent Statement: Not applicable.

Data Availability Statement: Data are available in a publicly accessible repository.

Acknowledgments: The authors are thankful to Wojciech Dragowski and Aleksandra Pietraszko for their technical help during the research.

Conflicts of Interest: The authors declare no conflict of interest.

\section{Appendix A}

The analytical method of mycotoxins determination in wheat grain by liquid chromatography coupled with tandem mass spectrometry is detailed herein.

\section{Appendix A.1. Wheat Sample Preparation}

Before analysis, samples were ground and stored at $-16{ }^{\circ} \mathrm{C}$. Sample was weighed $(5 \mathrm{~g})$ in a centrifuge tube and extracted with $10 \mathrm{~mL} 1 \% \mathrm{CH}_{2} \mathrm{O}_{2}$ in $\mathrm{C}_{2} \mathrm{H}_{3} \mathrm{~N}(1: 1, v / v)$. Next, $4 \mathrm{~g} \mathrm{MgSO}_{4}, 1 \mathrm{~g} \mathrm{NaCl}, 1 \mathrm{~g} \mathrm{Na}_{3} \mathrm{C}_{6} \mathrm{H}_{5} \mathrm{O}_{7}$, and $0.5 \mathrm{~g} \mathrm{HOC}(\mathrm{COOH})(\mathrm{CH} 2 \mathrm{COONa})_{2} \cdot 1.5 \mathrm{H}_{2} \mathrm{O}$ were added. The tubes were shaken $(1 \mathrm{~min})$, vortexed $(1 \mathrm{~min})$, and centrifuged for $5 \mathrm{~min}$ at $4500 \mathrm{rpm}$. Supernatant was collected in another tube $(15 \mathrm{~mL})$ and stored at $-60{ }^{\circ} \mathrm{C}$ for $30 \mathrm{~min}$. The extract $(5 \mathrm{~mL})$ was transferred to a centrifuge tube with $150 \mathrm{mg} \mathrm{MgSO}_{4}, 25 \mathrm{mg}$ PSA, and $25 \mathrm{mg} \mathrm{C} 15$. The samples were vortexed $(1 \mathrm{~min})$ and centrifuged at $4500 \mathrm{rpm}$ for $10 \mathrm{~min}$. The final extract $(1 \mathrm{~mL})$ was filtered through a $0.45 \mu \mathrm{m}$ hydrophilic PTFE filter to the autosampler vial and subsequently analyzed using LC-MS/MS.

\section{Appendix A.2. LC-MS/MS Analysis}

A liquid chromatography system (Eksigent Ultra LC-100; Eksigent Technologies, Dublin, CA, USA) was used at a flow rate of $0.5 \mathrm{~mL} \mathrm{~min}^{-1}$ without splitting. A KINETEX XB C18 $1.7 \mu \mathrm{m}, 2.1 \times 50 \mathrm{~mm}$ (Phenomenex) column was applied and heated to $40{ }^{\circ} \mathrm{C}$ during the analysis. A volume of $10 \mu \mathrm{L}$ was injected into the LC-MS/MS device. The binary mobile phase was composed of $\mathrm{H}_{2} \mathrm{O}+0.5 \% \mathrm{CH}_{2} \mathrm{O}_{2}+5 \mathrm{mM} \mathrm{NH}_{4} \mathrm{HCO}_{2}$ (phase A) and $\mathrm{CH}_{3} \mathrm{OH}+0.5 \% \mathrm{CH}_{2} \mathrm{O}_{2}+2 \mathrm{mM} \mathrm{NH}_{4} \mathrm{HCO}_{2}$ (phase $\mathrm{B}$ ). The following gradient elution was established: $95 \% \mathrm{~A}$ and $5 \% \mathrm{~B}(1 \mathrm{~min})$, rising gradually to $10 \% \mathrm{~A}$ and $90 \% \mathrm{~B}$ (6 min) and held for $3 \mathrm{~min}$. Next, the composition of the mobile phase changed to the initial condition and was held for $3 \mathrm{~min}$. Mass spectrometric analysis was conducted using a MS/MS 6500 QTRAP system (AB SCIEX Instruments, Foster City, CA, USA), coupled with an electrospray ionization source (ESI). The capillary voltage was set at $5000 \mathrm{~V}$ for the positive and $-4500 \mathrm{~V}$ for the negative ion mode. The turbo heater's temperature of $400{ }^{\circ} \mathrm{C}$ was maintained. Nitrogen was applied at a pressure of 60,50, and $30 \mathrm{psi}$, respectively, as the nebulizer gas (GS1), auxiliary gas (GS2), and curtain gas (CUR). Additionally, nitrogen was also used as the nebulizer and collision gas. The multiple reaction monitoring mode 
(MRM) was conducted to determine all mycotoxins. For each mycotoxin, the precursor ion and two product ions were determined: one product ion for quantification and one for qualification (Table A1).

Table A1. LC-MS/MS parameters for the determination of mycotoxin in wheat.

\begin{tabular}{|c|c|c|c|c|c|c|c|c|c|}
\hline \multirow[b]{2}{*}{ Mycotoxin } & \multicolumn{4}{|c|}{ Quantification } & \multicolumn{4}{|c|}{ Confirmation } & \multirow[b]{2}{*}{$\operatorname{EP}^{5}(\mathrm{~V})$} \\
\hline & ${ }^{\text {MRM Transition }}{ }^{1}$ & $\mathrm{DP}^{2}(\mathrm{~V})$ & $\mathrm{CE}^{3}(\mathrm{~V})$ & $\mathrm{CXP}^{4}(\mathrm{~V})$ & ${ }_{m / z}^{\text {MRM Transition }^{1}}$ & $\mathrm{DP}^{2}(\mathrm{~V})$ & $\mathrm{CE}^{3}(\mathrm{~V})$ & $\underset{(V)}{\text { CXP }^{4}}$ & \\
\hline \multicolumn{10}{|c|}{ POSITIVE ION MODE } \\
\hline 3-AcDON & $339>231$ & 70 & 17 & 16 & $339>203$ & 70 & 21 & 55 & 5 \\
\hline $15-\mathrm{AcDON}$ & $356>137$ & 46 & 21 & 8 & $339>137$ & 126 & 15 & 10 & 5 \\
\hline DAS & $367>307$ & 58 & 9 & 55 & $367>349$ & 58 & 11 & 24 & 5 \\
\hline FUM B1 & $722>334$ & 165 & 53 & 20 & $722>352$ & 165 & 51 & 22 & 5 \\
\hline FUM B2 & $706>336$ & 135 & 49 & 20 & $706>318$ & 135 & 53 & 18 & 5 \\
\hline FUM B3 & $706>336$ & 51 & 35 & 17 & $706>354$ & 51 & 29 & 21 & 5 \\
\hline HT-2 & $442.2>263$ & 61 & 17 & 30 & $442.2>215.1$ & 61 & 19 & 28 & 5 \\
\hline NEO & $400>185$ & 56 & 27 & 12 & $400>215$ & 51 & 17 & 14 & 5 \\
\hline $\mathrm{T}-2$ & $484.2>305.2$ & 76 & 19 & 20 & $484.2>215.1$ & 76 & 25 & 26 & 5 \\
\hline \multicolumn{10}{|c|}{ NEGATIVE ION MODE } \\
\hline $\mathrm{DON}$ & $355.1>295.1$ & -45 & -14 & -7 & $355.1>265.1$ & -45 & -20 & -15 & -5 \\
\hline FusX & $413.1>353$ & -50 & -14 & -7 & $413.1>263$ & -50 & -20 & -17 & -5 \\
\hline NIV & $371.1>311.1$ & -50 & -14 & -7 & $371.1>281$ & -50 & -20 & -17 & -5 \\
\hline $\mathrm{ZON}$ & $317.1>131.1$ & -85 & -38 & -9 & $317.1>175$ & -85 & -32 & -11 & -5 \\
\hline
\end{tabular}

${ }^{1}$ Multiple reaction monitoring mode; ${ }^{2}$ declustering potential; ${ }^{3}$ collision energy; ${ }^{4}$ cell exit potential; ${ }^{5}$ entrance potential.

\section{Appendix A.3. Validation Protocol}

During the validation study of the analytical method, the following parameters were determined: the accuracy (recovery), precision, limit of detection (LOD), limit of quantification (LOQ), linearity, deviation of the back-calculated concentration (DEV), matrix effect (ME), and uncertainty (U).

Four enrichment levels (LOQ, 10, 50, and $200 \mu \mathrm{g} \mathrm{kg}^{-1}$ ) were prepared to the evaluate accuracy (average recovery) and precision (relative standard deviation, RSD). The range of recoveries of $70-120 \%$ was acceptable with a repeatability of $\leq 20 \%$ (RSD $\leq 20 \%$ ). Recovery rates outside the range of $70-120 \%$ were accepted if consistent (RSD $\leq 20 \%$ ), but the recovery should not be lower than $30 \%$ or above $140 \%$ [23]. As seen in Table A2, most of the mycotoxins presented satisfactory recoveries within the range between $70 \%$ and $120 \%$, with RSD values $\leq 20 \%$, i.e., compliant with the SANTE criteria (Table A2). Only toxin T-2 showed a recovery slightly above $120 \%(132 \%)$ at the lowest spiking level of $0.1 \mathrm{\mu g} \mathrm{kg}^{-1}$ with an acceptable RSD value (15\%).

The limits of detection (LOD) and limits of quantification (LOQ) were calculated for a signal-to-noise ratio (S/N) of 3 and 10, respectively, by spiking the wheat sample at the concentration of $5 \mu \mathrm{g} \mathrm{kg}^{-1}$. The determined values were included in Table A2.

Matrix-matched calibration at six different concentration levels of LOQ-5, 10, 25, 50, 200 and $500 \mu \mathrm{g} \mathrm{kg}^{-1}$ — was used to study linearity, and DEV was calculated as follows: $\%$ DEV $\left.=\left(C_{\text {measured }}-C_{\text {true }}\right) \times 100 / C_{\text {true }}\right)[23]$. The method used in this study achieved a good linearity with a DEV lower than $\pm 20 \%$ (between $-16 \%$ and $18 \%$ ) (Table A3).

To estimate the matrix effects for all analyzed analytes, the same calibration curves in the pure solvent (acetonitrile) were compared with the calibration curves obtained during the matrix-matched calibration. MEs were calculated with the following formula: $\% \mathrm{ME}=(($ peak area $($ matrix standard $) /$ peak area $($ solvent standard $))-1) \times 100$. The positive values mean the matrix effect is enhanced, while the negative values mean the matrix effect is suppressed. If the matrix effects fell below $-50 \%$ or above $+50 \%$, it was considered a strong effect, while it was considered a soft $(-20 \%<$ MEs $<20 \%)$ or a medium effect when the values were between $-50 \%<$ MEs $<-20 \%$ and $50 \%>$ MEs $>20 \%$. The sample extraction and purification procedure used in this study allowed a soft matrix effect to be obtained for all tested mycotoxins. The obtained values ranged from $-16 \%$ to $19 \%$ (Table A2). The uncertainty of measurement was calculated individually for each analyte and estimated based on the data obtained in the validation study. The relative expanded uncertainty 
was estimated by applying a "top-down" empirical model with coverage factor $\mathrm{k}=2$ at a $95 \%$ confidence level. In all cases, the expanded uncertainty was acceptable and ranged from $11 \%$ to $21 \%$ (Table A2), and was less than the default value of $50 \%$ recommended by SANTE.

Table A2. Average recoveries, RSDs, LODs, LOQs, and expanded uncertainties $\mathrm{U}, \%(\mathrm{k}=2$, confidence level 95\%) of mycotoxin in wheat.

\begin{tabular}{|c|c|c|c|c|c|c|c|c|}
\hline \multirow[b]{2}{*}{ Mycotoxin } & \multirow{2}{*}{$\underset{\left(\mu \mathrm{g} \mathrm{kg}^{-1}\right)}{\mathrm{LOD}^{1}}$} & \multirow{2}{*}{$\begin{array}{c}\mathrm{LOQ}^{2} \\
\left(\mu \mathrm{g} \mathrm{kg}^{-1}\right)\end{array}$} & \multicolumn{4}{|c|}{ Recovery $\left(\right.$ RSD $\left.^{3}\right)(\%)$} & \multirow[b]{2}{*}{$\operatorname{ME}^{4}(\%)$} & \multirow[b]{2}{*}{$\mathrm{U}^{5}(\%)$} \\
\hline & & & $\begin{array}{l}\text { 1st Level } \\
=\text { LOQ }\end{array}$ & $\begin{array}{c}\text { 2nd Level } \\
10\left(\mu \mathrm{kg}^{-1}\right)\end{array}$ & $\begin{array}{c}\text { 3rd Level } \\
50.0\left(\mu \mathrm{kg}^{-1}\right)\end{array}$ & $\begin{array}{c}\text { 4th Level } \\
200.0\left(\mu \mathrm{g} \mathrm{kg}^{-1}\right)\end{array}$ & & \\
\hline 15-AcDON & 0.3 & 1 & $95(14)$ & $93(10)$ & $77(4)$ & $94(4)$ & -13 & 11 \\
\hline 3-AcDON & 0.4 & 1 & $94(15)$ & $112(14)$ & $86(7)$ & $72(14)$ & -10 & 13 \\
\hline DAS & 0.2 & 0.5 & $86(7)$ & $82(8)$ & $86(7)$ & $76(6)$ & 14 & 19 \\
\hline DON & 1.5 & 5 & $73(18)$ & $72(7)$ & $78(8)$ & $98(7)$ & -5 & 11 \\
\hline FUM B1 & 0.3 & 1 & $112(3)$ & $101(4)$ & $101(4)$ & $78(8)$ & 8 & 20 \\
\hline FUM B2 & 0.2 & 1 & $96(6)$ & $95(5)$ & $94(6)$ & $98(5)$ & 11 & 21 \\
\hline FUM B3 & 0.25 & 1 & $65(7)$ & $66(5)$ & $69(5)$ & $100(4)$ & -6 & 14 \\
\hline FusX & 0.6 & 2 & 77 (3) & $79(6)$ & $78(7)$ & $74(6)$ & -9 & 11 \\
\hline HT-2 & 0.3 & 1 & 75 (9) & $76(8)$ & 79 (6) & $82(6)$ & -16 & 17 \\
\hline NEO & 0.65 & 2 & $70(7)$ & 77 (14) & $80(7)$ & 81 (5) & 19 & 13 \\
\hline NIV & 0.35 & 1 & 94 (13) & $82(11)$ & $106(4)$ & 88 (5) & 11 & 14 \\
\hline $\mathrm{T}-2$ & 0.03 & 0.1 & $132(15)$ & $99(15)$ & $103(5)$ & $84(6)$ & -7 & 13 \\
\hline $\mathrm{ZON}$ & 0.35 & 1 & $90(5)$ & $93(7)$ & $100(4)$ & $94(5)$ & 12 & 14 \\
\hline
\end{tabular}

${ }^{1}$ Limit of detection; ${ }^{2}$ limit of quantification; ${ }^{3}$ relative standard deviation; ${ }^{4}$ matrix effect; ${ }^{5}$ uncertainty.

Table A3. Regression equations and deviation of the back-calculated concentration (DEV) of mycotoxins in wheat.

\begin{tabular}{|c|c|c|c|c|c|c|c|c|}
\hline Mycotoxin & Regression Equation & $\begin{array}{l}\text { DEV }(\%) \\
\text { LOQ }^{1}\end{array}$ & $\begin{array}{c}\mathrm{DEV} \mathrm{( \% )} \\
5.0\left(\mu \mathrm{g} \mathrm{kg}^{-1}\right)\end{array}$ & $\begin{array}{c}\text { DEV (\%) } \\
10.0\left(\mathrm{\mu g} \mathrm{kg}^{-1}\right)\end{array}$ & $\begin{array}{c}\text { DEV (\%) } \\
25.0\left(\mu \mathrm{g} \mathrm{kg}^{-1}\right)\end{array}$ & $\begin{array}{c}\mathrm{DEV} \mathrm{( \% )} \\
50.0\left(\mu \mathrm{gg}^{-1}\right)\end{array}$ & $\begin{array}{c}\text { DEV (\%) } \\
200.0\left(\mu \mathrm{kg}^{-1}\right)\end{array}$ & $\begin{array}{c}\text { DEV (\%) } \\
500.0\left(\mu \mathrm{g} \mathrm{kg}^{-1}\right)\end{array}$ \\
\hline 15-AcDON & $\mathrm{y}=4.1797 \mathrm{x}-0.0101$ & 17 & 13 & -7 & 3 & 4 & -1 & 1 \\
\hline 3-AcDON & $y=1.8211 x-0.0060$ & 5 & 9 & 2 & 1 & 10 & 2 & 3 \\
\hline DAS & $y=1.2567 x-0.0014$ & -11 & 6 & -6 & 14 & -6 & 5 & -2 \\
\hline DON & $y=8.0287 x+0.0005$ & & 8 & 8 & -15 & 12 & 1 & -1 \\
\hline FUM B1 & $\mathrm{y}=1.4562 \mathrm{x}+3.7151$ & -3 & 1 & 5 & -3 & 3 & 2 & -1 \\
\hline FUM B2 & $y=1.8879 x+2.6171$ & -4 & 11 & 10 & 3 & -4 & -2 & -1 \\
\hline FUM B3 & $y=0.0019 x-0.0071$ & -3 & 12 & -6 & 4 & -7 & 10 & -1 \\
\hline FusX & $\mathrm{y}=0.0021 \mathrm{x}-0.0281$ & 11 & 8 & 18 & -8 & 9 & 3 & -4 \\
\hline HT-2 & $y=4.4066 x-1.9306$ & 17 & 3 & 1 & 2 & 3 & 3 & 2 \\
\hline NEO & $y=1.8879 x+2.6171$ & -4 & 2 & 5 & -1 & -2 & 6 & -1 \\
\hline NIV & $\mathrm{y}=0.0019 x-0.0071$ & -3 & 9 & 11 & -16 & -7 & 11 & -1 \\
\hline $\mathrm{T}-2$ & $y=0.0030 x-0.0109$ & -10 & -2 & 6 & -5 & 3 & 4 & -4 \\
\hline ZON & $\mathrm{y}=5.9983 \mathrm{x}-1.0007$ & 9 & 6 & -7 & 5 & -9 & -4 & -1 \\
\hline
\end{tabular}

${ }^{1}$ Limit of quantification.

\section{References}

1. Rodehutscord, M.; Ruckert, C.; Maurer, H.P.; Schenkel, H.; Schipprack, W.; Knudsen, K.E.B.; Schollenberger, M.; Laux, M.; Eklund, M.; Sieger, W.; et al. Variation in chemical composition and physical characteristics of cereal grains from different genotypes. Arch. Anim. Nutr. 2016, 70, 87-107. [CrossRef] [PubMed]

2. OECD/FAO. Agricultural Outlook 2019-2028; OECD Publishing: Paris, France; Paris/Food and Agriculture Organization of the United Nations: Rome, Italy, 2019.

3. Castro, A.C.; Simon, M.R. Effect of tolerance to Septoria tritici blotch on grain yield, yield components and grain quality in Argentinean wheat cultivars. Crop Prot. 2016, 90, 66-76. [CrossRef]

4. Iwaniuk, P.; Konecki, R.; Snarska, K.; Lozowicka, B. Quantitative evaluation of Fusarium species and crop quality traits in wheat varieties of northeastern Poland. J. Plant Prot. Res. 2018, 58, 413-419.

5. Dweba, C.C.; Figlan, S.; Shimelis, H.A.; Motaung, T.E.; Sydenham, S.; Mwadzingeni, L.; Tsilo, T.J. Fusarium head blight of wheat: Pathogenesis and control strategies. Crop Prot. 2017, 91, 114-122. [CrossRef]

6. Pszczolkowska, A.; Okorski, A.; Fordonski, G.; Kotecki, A.; Kozak, M.; Dzienis, M. Effect of weather conditions on yield and health status of Faba bean seeds in Poland. Agronomy 2020, 10, 48. [CrossRef]

7. Gruber-Dorninger, C.; Jenkins, T.; Schatzmayr, G. Global mycotoxin occurrence in feed: A ten-year survey. Toxins 2019, 11, 375. [CrossRef] [PubMed]

8. Nugmanov, A.; Beishova, I.; Kokanov, S.; Lozowicka, B.; Kaczynski, P.; Konecki, R.; Snarska, K.; Wolejko, E.; Sarsembayeva, N.; Abdigaliyeva, T. Systems to reduce mycotoxin contamination of cereals in the agricultural region of Poland and Kazakhstan. Crop Prot. 2018, 106, 64-71. [CrossRef]

9. European Food Safety Authority (EFSA). Evaluation of the increase of risk for public health related to a possible temporary derogation from the maximum level of deoxynivalenol, zearalenone and fumonisins for maize and maize products. EFSA J. 2014, 12,3699 . 
10. Commission Regulation (EU) 1881/2006 of 19 December 2006. Setting maximum levels for certain contaminants in foodstuffs. Off. J. L. 2006, 364, 5-24.

11. Wei, X.; Xu, Z.; Zhang, N.; Yang, W.; Liu, D.; Ma, L. Synergistic action of commercially available fungicides for protecting wheat from common root rot caused by bipolaris sorokiniana in China. Plant Dis. 2020, 105, 667-674. [CrossRef]

12. Bashir, M.R.; Atiq, M.; Sajid, M.; Mohsan, M.; Abbas, W.; Alam, M.W.; Bashair, M. Antifungal exploitation of fungicides against Fusarium oxysporum f. sp. capsici causing Fusarium wilt of chilli pepper in Pakistan. Environ. Sci. Pollut. Res. Int. 2018, 25, 6797-6801. [CrossRef]

13. Martelloni, L.; Frasconi, C.; Sportelli, M.; Fontanelli, M.; Raffaelli, M.; Peruzzi, A. Flaming, glyphosate, hot foam and nonanoic acid for weed control: A comparison. Agronomy 2020, 10, 129. [CrossRef]

14. Wolejko, E.; Lozowicka, B.; Kaczynski, P.; Konecki, R.; Grobela, M. The influence of chemical protection on the content of heavy metals in wheat (Triticum aestivum L.) growing on the soil enriched with granular sludge. Environ. Monit. Assess. 2017, 189, 424. [CrossRef]

15. Faligowska, A.; Panasiewicz, K.; Szymańska, G.; Ratajczak, K.; Sulewska, H.; Pszczółkowska, A.; Kocira, A. Influence of farming system on weed infestation and on productivity of narrow-leaved lupin (Lupinus angustifolius L.). Agriculture 2020, 10, 459. [CrossRef]

16. Lozowicka, B.; Konecki, R.; Iwaniuk, P.; Dragowski, W.; Rusilowska, J.; Pietraszko, A.; Snarska, K. Effect of a biostimulator and herbicidal protection on weed infestation as well as quantitative and qualitative parameters of spring wheat crop yield. Prog. Plant Prot. 2019, 59.

17. Popko, M.; Michalak, I.; Wilk, R.; Gramza, M.; Chojnacka, K.; Gorecki, H. Effect of the new plant growth biostimulants based on amino acids on yield and grain quality of winter wheat. Molecules 2018, 23, 470. [CrossRef]

18. Elansary, H.O.; Mahmoud, E.A.; El-Ansary, D.O.; Mattar, M.A. Effects of water stress and modern biostimulants on growth and quality characteristics of mint. Agronomy 2020, 10, 6. [CrossRef]

19. Matysiak, K.; Miziniak, W.; Kaczmarek, S.; Kierzek, R. Herbicides with natural and synthetic biostimulants in spring wheat. Cienc. Rural 2018, 48, e20180405. [CrossRef]

20. Maignan, V.; Geliot, P.; Avice, J.-C. Glutacetine ${ }^{\circledR}$ biostimulant applied on wheat under contrasting field conditions improves grain number leading to better yield, upgrades n-related traits and changes grain ionome. Plants 2021, 10, 456. [CrossRef]

21. Gunupuru, L.R.; Patel, J.S.; Sumarah, M.W.; Renaud, J.B.; Mantin, E.G.; Prithiviraj, B. A plant biostimulant made from the marine brown algae Ascophyllum nodosum and chitosan reduce Fusarium head blight and mycotoxin contamination in wheat. PLoS ONE 2019, 14, e0220562. [CrossRef]

22. Iwaniuk, P.; Lozowicka, B.; Kaczynski, P.; Konecki, R. Multifactorial wheat response under Fusarium culmorum, herbicidal, fungicidal and biostimulator treatments on the biochemical and mycotoxins status of wheat. J. Saudi Soc. Agric. Sci. 2021, 20, 443-453. [CrossRef]

23. SANTE Document No. SANTE/11813/2017. Guidance Document on Analytical Quality Control and Method Validation Procedures for Pesticides Residues Analysis in Food and Feed. 2017. Available online: https://ec.europa.eu/food/sites/food/ files/plant/docs/pesticides_mrl_guidelines_wrkdoc_2017-11813.pdf (accessed on 19 January 2022).

24. Varshney, S.; Hayat, S.; Alyemeni, M.N.; Ahmad, A. Effects of herbicide applications in wheat fields. Plant Signal. Behav. 2012, 7 , 570-575. [CrossRef]

25. Zahan, T.; Hossain, M.F.; Chowdhury, A.K.; Ali, M.O.; Ali, M.A.; Dessoky, E.S.; Hassan, M.M.; Maitra, S.; Hossain, A. Herbicide in weed management of wheat (Triticum aestivum L.) and rainy season rice (Oryza sativa L.) under conservation agricultural system. Agronomy 2021, 11, 1704. [CrossRef]

26. Mystkowska, I. Biostimulators as a factor affecting the dry matter yield and starch content of edible potato tubers. Acta Agrophys. 2015, 26, 37-45. [CrossRef]

27. Fones, H.; Gurr, S. The impact of Septoria tritici Blotch disease on wheat: An EU perspective. Fungal Genet. Biol. 2015, 79, 3-7. [CrossRef]

28. Busko, M.; Stuper, K.; Jelen, H.; Goral, T.; Chmielewski, J.; Tyrakowska, B.; Perkowski, J. Comparison of volatiles profile and contents of trichothecenes group B, ergosterol, and ATP of bread wheat, durum wheat, and triticale grain naturally contaminated by mycobiota. Front. Plant Sci. 2016, 7, 1243. [CrossRef]

29. Masiello, M.; Somma, S.; Ghionna, V.; Logrieco, A.F.; Moretti, A. In vitro and in field response of different fungicides against Aspergillus flavus and Fusarium species causing ear rot disease of maize. Toxins 2019, 11, 11. [CrossRef]

30. Martinez, D.A.; Loening, U.E.; Graham, M.C. Impacts of glyphosate-based herbicides on disease resistance and health of crops: A review. Environ. Sci. Eur. 2018, 30, 2. [CrossRef] [PubMed]

31. Sanyal, D.; Shrestha, A. Direct effect of herbicides on plant pathogens and disease development in various cropping systems. Weed Sci. 2008, 56, 155-160. [CrossRef]

32. Gonzalez-Dominguez, E.; Meriggi, P.; Ruggeri, M.; Rossi, V. Efficacy of fungicides against Fusarium Head Blight depends on the timing relative to infection rather than on wheat growth stage. Agronomy 2021, 11, 1549. [CrossRef]

33. Tola, M.; Kebede, B. Occurrence, importance and control of mycotoxins: A review. Food Sci. Technol. 2016, 2, 1191103. [CrossRef]

34. Haliniarz, M.; Gawęda, D.; Nowakowicz-Dębek, B.; Najda, A.; Chojnacka, S.; Łukasz, J.; Wlazło, Ł.; Różańska-Boczula, M Evaluation of the weed infestation, grain health, and productivity parameters of two spelt wheat cultivars depending on crop protection intensification and seeding densities. Agriculture 2020, 10, 229. [CrossRef] 
35. Marques, L.N.; Pizzutti, I.R.; Balardin, R.S.; Santos, I.D.D.; Dias, J.V.; Stefanello, M.T.; Serafini, P.T. Occurrence of mycotoxins in wheat grains exposed to fungicides on fusarium head blight control in southern Brazil. J. Environ. Sci. Health B 2017, 52, 244-250. [CrossRef] [PubMed]

36. Da Luz, S.R.; Pazdiora, P.C.; Dallagnol, L.J.; Dors, G.C.; Chaves, F.C. Mycotoxin and fungicide residues in wheat grains from fungicide-treated plants measured by a validated LC-MS method. Food Chem. 2017, 220, 510-516. [CrossRef]

37. Goral, T.; Wisniewska, H.; Ochodzki, P.; Nielsen, L.K.; Walentyn-Goral, D.; Stepien, L. Relationship between Fusarium Head Blight, kernel damage, concentration of Fusarium biomass, and Fusarium toxins in grain of winter wheat inoculated with Fusarium culmorum. Toxins 2019, 11, 2. [CrossRef]

38. Mystkowska, I.; Zarzecka, K.; Baranowska, A.; Gugala, M. An effect of herbicides and their mixtures on potato yielding and efficacy in potato crop. Prog. Plant Prot. 2017, 57, 21-26.

39. Baranowska, A.; Mystkowska, I.; Zarzecka, K. The weed infestation of the potato (Solanum tuberosum L.) field under the conditions of growth biostymulators and herbicide applications. Prog. Plant Prot. 2018, 58, 275-281.

40. Feledyn-Szewczyk, B.; Cacak-Pietrzak, G.; Lenc, L.; Stalenga, J. Rating of spring wheat varieties (Triticum aestivum L.) according to their suitability for organic agriculture. Agriculture 2020, 10, 1900. [CrossRef]

41. Stanciu, O.; Juan, C.; Berrada, H.; Miere, D.; Loghin, F.; Manes, J. Study on trichothecene and zearalenone presence in Romanian wheat relative to weather conditions. Toxins 2019, 11, 163. [CrossRef] [PubMed]

42. Gerhards, R.; Ouidoh, F.N.; Adjogboto, A.; Avohou, V.A.P.; Dossounon, B.L.S.; Adisso, A.K.D.; Heyn, A.; Messelhäuser, M.; Santel, H.-J.; Oebel, H. Crop response to leaf and seed applications of the biostimulant ComCat ${ }^{\circledR}$ under stress conditions. Agronomy 2021, 11, 1161. [CrossRef]

43. Hossard, L.; Philibert, A.; Bertrand, M.; Colnenne-David, C.; Debaeke, P.; Munier-Jolain, N.; Jeuffroy, M.H.; Richard, G.; Makowski, D. Effects of halving pesticide use on wheat production. Sci. Rep. 2014, 4, 4405. [CrossRef]

44. Brankov, M.; Simic, M.; Dragicevic, V. The influence of maize-winter wheat rotation and pre-emergence herbicides on weeds and maize productivity. Crop Prot. 2021, 143, 105558. [CrossRef]

45. Landschoot, S.; Audenaert, K.; Waegeman, W.; De Baets, B.; Haesaert, G. Influence of maize-wheat rotation systems on Fusarium head blight infection and deoxynivalenol content in wheat under low versus high disease pressure. Crop Prot. 2013, 52, 14-21, 43. [CrossRef]

46. Lynch, J.P.; Glynn, E.; Kildea, S.; Spink, J. Yield and optimum fungicide dose rates for winter wheat (Triticum aestivum L.) varieties with contrasting ratings for resistance to septoria tritici blotch. Field Crops Res. 2017, 204, 89-100. [CrossRef] 